\title{
Vaccine Apartheid? A Human Rights Analysis of COVID-19 Vaccine Inequity
}

\author{
Sarah Joseph* and Gregory Dore**
}

The COVID-19 pandemic has changed the way life is lived in almost every corner of the globe, and has killed millions of people. Yet it has also given rise to an extraordinary triumph in medical science, the production of several highly effective safe vaccines for a novel virus within a year of that virus's appearance. The positive results from clinical trials are now being mirrored in real-world circumstances: the numbers regarding COVID-19 deaths and hospitalisations are plummeting in states with high vaccination rates such as Israel and the United Kingdom.

While some countries can reasonably aspire to the mass vaccination of those willing and able to receive it, many states, particularly less developed ones, may need to wait until 2024 for such an outcome. ${ }^{1}$ The current situation is thus characterised by extreme inequity at a global level regarding access to a COVID-19 vaccine, which we will refer to as 'vaccine inequity'.

The World Health Organisation ('WHO') has repeatedly condemned vaccine inequity. In January 2021, the Director General of the WHO, Dr Tedros Adhanom Ghebreyesus, described it as 'a catastrophic moral failure - and the price of this failure will be paid with lives and livelihoods in the world's poorest countries'. ${ }^{2}$

In this paper, we analyse vaccine inequity under international human rights law. In Part 1, we introduce the currently available COVID-19 vaccines, before discussing causes and consequences of vaccine inequity, as well as current efforts to expand global vaccine access. In Part 2, we turn to explain the relevant, including extraterritorial, obligations of states regarding human rights to health, life, and equitable access to the benefits of technology. In light of those obligations, we assess the human rights compatibility of the following circumstances which hinder and facilitate vaccine access: embargoes on vaccines; national procurement and vaccine hoarding; and vaccine aid. Part 2 concludes with a short discussion of the possible human rights responsibilities of the entities that own the vaccines, multinational pharmaceutical companies. In Part 3, we analyse proposals to waive global intellectual property rights in respect of COVID-19 vaccines, and whether assent to such a waiver is demanded under international human rights law. Part 4 concludes this paper.

\footnotetext{
* Professor of Human Rights Law, Griffith University, Brisbane. I thank Dr Joanna Kyriakakis and Dr Michelle Rourke for their excellent feedback on this paper, and Gian Chung for her work on the finalisation of the paper.

** Professor of Epidemiology, Kirby Institute, University of New South Wales, Sydney.

${ }^{1}$ Economist Intelligence Unit, 'The EIU's latest vaccine rollout forecasts', 28 April 2021, https://www.eiu.com/n/eiu-latest-vaccine-rollout-forecasts/.

2 U.N., WHO Chief Warns Against 'Catastrophic Moral Failure' in COVID-19 Vaccine Access, U.N.: U.N. News (18 Jan. 2021), https://news.un.org/en/story/2021/01/1082362.
} 


\section{Part 1: COVID-19 Vaccines, Causes and Consequences of Inequity in Access}

\section{Different Types of COVID-19 Vaccines:}

The development of several safe and effective vaccines within a year of recognition of the COVID-19 disease, and identification of SARS-CoV-2 as its causative agent, is remarkable. Most vaccines take years to develop. Key factors in this accelerated development include prior work on similar viruses, notably Severe Acute Respiratory Syndrome coronavirus (SARS-CoV) and Middle Eastern Respiratory Syndrome coronavirus (MERS-CoV), improved technology for vaccine platforms, massive scientific and monetary investment, and the high rates of ongoing COVID-19 enabling rapid enrolment and accrual of events for phase 3 clinical trial endpoints.

COVID-19 vaccines are largely based on the pivotal S (Spike) protein that enables binding and cell entry, with four broad classes among those currently licensed:

Protein sub-unit vaccines: With these vaccines, the $\mathrm{S}$ protein is delivered as a recombinant protein subunit that incorporates a cell-based system to enable expression of the protein (e.g. Novavax).

Viral vector vaccines: These vaccines use adenoviruses, themselves unable to replicate, to deliver and express the S protein (e.g. AstraZeneca/Oxford; Johnson \& Johnson, Sputnik V, Cansino). Several other adenovirus vaccines have been trialled against infectious diseases (HIV, Tuberculosis, malaria, ebola) with variable success.

mRNA vaccines: With these vaccines, $\mathrm{S}$ protein-encoding $\mathrm{mRNA}$ is protected within lipid nanoparticles that has instructions for making $S$ protein, thus stimulating protective neutralizing antibodies and other elements of the immune response against SARS-CoV-2 (e.g. Pfizer, Moderna). These types of vaccines are clearly the "new kid on the block" as this technology has not previously been approved for use in humans.

Whole attenuated virus vaccines: These vaccines contain inactivated SARS-CoV-2 that can present the key antigens to simulate an effective immune response, but without producing infection (e.g. Sinovac, Simopharm).

Phase 3 clinical trials have generally shown efficacy against symptomatic SARS-CoV-2 (COVID-19) in the range of 70-95\%, which underpins the optimism that their development has brought. ${ }^{3}$ Additionally, efficacy against severe COVID-19 or hospitalization has been close to $100 \%$ in clinical trials and above $90 \%$ in "real-world" studies. ${ }^{4}$ Furthermore, increasing evidence from these trials and real-world evaluation indicates probably at least

\footnotetext{
${ }^{3}$ See Jerome H. Kim et al, 'Looking beyond COVID-19 vaccination phase 3 trials', 27 Nature Medicine 205 (2021).

${ }^{4}$ See Public Health England, 'Vaccines highly effective against hospitalisation from Delta variant', https://www.gov.uk/government/news/vaccines-highly-effective-against-hospitalisation-from-delta-variant, 14 June 2021.
} 
70\% reduction and possibly higher effectiveness against infections. ${ }^{5}$ There is also evidence that the minority of people who do develop "breakthrough" infections post-vaccination have lower viral levels and are thus likely less infectious, further enhancing their potential impact on population-level transmission. ${ }^{6}$

The capacity to reach "herd immunity", whereby risk of SARS-CoV-2 spread is limited due to high population-level immunity through vaccination and natural infection, is dependent on several factors. The level of vaccine coverage required has often been stated at greater than $70 \%$, but it depends on the level of vaccine efficacy (against all infections), the impact of vaccination on infectivity, and the transmission potential of currently circulating variants. Given, as at the time of writing, new variants with increased infectivity, limited vaccination for those under 16 years of age, and some degree of vaccine hesitancy within all populations, herd immunity does not appear to be feasible in the near future. A more realistic goal is to achieve "disease immunity", whereby high levels of vaccine uptake, particularly among older adults and those with underlying medical conditions, will markedly reduce the risk of severe COVID-19 and deaths.

\section{Initiatives to improve Accessibility}

By March 2021, an estimated 413 million COVID-19 vaccine doses had been manufactured. ${ }^{7}$ Around 11 billion doses (assuming two dose schedule) are required to vaccinate $70 \%$ of the world's population. Contracts for the delivery of around 8.6 billion doses have been signed, but 6 billion of these doses have been secured by high and upper-middle income countries who constitute only $20 \%$ of the global population. Many rich countries have contracted for the delivery of considerably more doses than required, including Australia and Canada with contracts for around three-fold their populations. ${ }^{8}$

There are several major regional and global initiatives directed towards addressing this stark inequity through enhanced COVID-19 vaccine access for all countries, including the following.

COVAX facility: The COVID-19 Vaccines Global Access (COVAX) is an international initiative led by WHO, Gavi (The Global Vaccine Alliance, an international public-private partnership established in 2000 to increase vaccine access in poor countries), and CEPI (Coalition for Epidemic Preparedness, a Gates Foundation initiative established in 2016 to enhance vaccine development), with UNICEF as a key delivery partner. ${ }^{9}$ COVAX is a vaccine

\footnotetext{
${ }^{5}$ Emma Pritchard et al., Impact on Vaccination on SARS-CoV-2 Cases in the Community: A Population-Based Study Using the UK's COVID-19 Infection Survey (unpublished manuscript) (on file with MedRxiv), https://www.ndm.ox.ac.uk/files/coronavirus/ciscommunityvaccinationpaper20210417complete.pdf.

${ }^{6}$ Ross J. Harris et al., Impact of Vaccination on Household Transmission of SARS-COV-2 in England (unpublished manuscript) (on file with Knowledge Hub),

https://khub.net/documents/135939561/390853656/Impact+of+vaccination+on+household+transmission+of+ SARS-COV-2+in+England.pdf/35bf4bb1-6ade-d3eb-a39e-9c9b25a8122a?t=1619601878136.

${ }^{7}$ Aisling Irwin, 'What will it take to vaccinate the world against COVID-19?", Nature, 25 March 2021, https://www.nature.com/articles/d41586-021-00727-3

${ }^{8} \mathrm{See}$, eg, https://www.health.gov.au/initiatives-and-programs/covid-19-vaccines/covid-19-vaccinegovernment-response/australias-vaccine-agreements.

${ }^{9}$ Gavi: The Vaccine Alliance, https://www.gavi.org/covax-facility (last visited June 7, 2021).
} 
procurement and distribution mechanism to enable global COVID-19 vaccine access, with an initial goal of $20 \%$ population coverage for around 200 participating countries by the end of 2021. After the $20 \%$ point, vaccines would be allocated according to need determined by COVID-19 threat and vulnerability. ${ }^{10}$ The $20 \%$ threshold could provide crucial disease protection for more vulnerable populations including the elderly, but would not have major impacts on spread: ${ }^{11}$ COVAX suffered a major blow in April 2021 when a large allocation of the AstraZeneca vaccine to it was delayed: the allocation was coming from the Serum Institute of India, which was forced to switch its focus to supply India in the midst of a devastating domestic COVID-19 wave. ${ }^{12}$

QUAD: This four-member partnership between United States, India, Australia, and Japan has previously focussed on strategic relationships including military co-operation, and has been seen as a grouping to balance the increasing role of China within the Asia-Pacific Region. In March 2021, political leaders of the four countries announced an initiative to enhance AsiaPacific regional COVID-19 vaccine access with a goal to provide one billion doses by 2022. Initial efforts will involve funding by the United States, manufacturing of the Johnson \& Johnson vaccine by India and Japan, and logistical support by Australia. ${ }^{13}$

Bilateral agreements: China and Russia have been very active in support for global vaccine access. China has estimated that it can produce 2.6 billion doses in 2021, and has pledged half a billion vaccine doses to more than 80 countries, providing free doses for 53 of those, including states across South East Asia and Africa. ${ }^{14}$ Russia has concentrated its efforts on bilateral agreements for supply of its Sputnik V vaccine in Latin America and Eastern Europe. Although criticisms of Chinese and Russian 'vaccine diplomacy' have been made in relation to these initiatives, other international initiatives such as QUAD clearly also encompass strategic considerations. Other bilateral agreements also exist, such as an agreement for Australia to provide vaccines to Papua New Guinea and Melanesian islands. ${ }^{15}$

\footnotetext{
${ }^{10}$ WHO, https://www.who.int/publications/m/item/allocation-mechanism-for-covax-facility-vaccinesexplainer.

${ }^{11}$ Amy Kapczynski, How to Vaccinate the World, Part 1, Law and Political Economy Project Blog (Apr. 30, 2021), https://Ipeproject.org/blog/how-to-vaccinate-the-world-part-1/. Public Citizen, Waiver of the WTO's Intellectual Property Rules: Facts vs. Common Myths, Public Citizen: COVID Vaccines For All: WHO TRIPS Waiver Now (Mar. 29, 2021), https://www.citizen.org/article/waiver-of-the-wtos-intellectual-property-rules-myths-vsfacts/. Siva Thambisetty et al., The TRIPS Intellectual Property Waiver Protocol: Creating the Right Incentives in Patent Law and Politics to End the COVID-19 Pandemic (2021), SSRN, https://papers.ssrn.com/sol3/papers.cfm?abstract id=3851737, 17 (24 May 2021).

${ }_{12}$ Amy Kapczynski, How to Vaccinate the World, Part 1, Law and Political Economy Project Blog (Apr. 30, 2021), https://lpeproject.org/blog/how-to-vaccinate-the-world-part-1/; Achal Prabhala \& Leena Menghaney, The World's Poorest Countries are at India's Mercy for Vaccines. It's Unsustainable, The Guardian (Apr. 2, 2021, 7:00 PM), https://www.theguardian.com/commentisfree/2021/apr/02/india-in-charge-of-developing-worldcovid-vaccine-supply-unsustainable; Siva Thambisetty et al., 10.

${ }^{13}$ The White House, Fact Sheet: Quad Summit (Mar. 12, 2021).

${ }^{14}$ Suisheng Zhao, Why China's Vaccine Diplomacy is Winning, East Asia Forum: COVID-19 (Apr. 29, 2021), https://www.eastasiaforum.org/2021/04/29/why-chinas-vaccine-diplomacy-is-winning/.

${ }^{15}$ Stephen Dziedzic, 'Australia to supply doses of domestically manufactured COVID-19 vaccines to Melanesian countries, including PNG and Timor-Leste', ABC News, 9 April 2021, https://www.abc.net.au/news/2021-0409/australia-png-covid-vaccine-supply-melanesian-countries/100060206
} 
All of these initiatives are welcome. However, they do not go far enough in delivering vaccines quickly to most of the world.

\section{Causes of Inequitable Access}

Inequitable access to the vaccines is driven by many factors. In early 2021 , the obvious reason is that demand outstrips supply. Access is currently a zero-sum game where one country's increased access inevitably reduces the availability of vaccines for other countries. Amidst such scarcity, developed states have bought the vast majority of available vaccines directly from manufacturers, and have advance purchased most of the vaccines scheduled to be manufactured in $2021 .^{16}$

Logistical limitations also affect access. Access is easier in those states with the capacity to manufacture the vaccines compared to those who must import it. This is especially so, given export blockades have arisen to prioritise local access in emergency situations (discussed below). Other logistical issues concern the safe and effective rollout of vaccines, such as keeping vaccines at appropriate refrigerated temperatures while they are transported and stored.

Finally, vaccine manufacturers have monopoly rights over their products, which allows them to control manufacture and distribution networks. The monopoly rights of vaccine manufacturers are discussed in detail in Part 3.

\section{Consequences of Vaccine Inequity}

Specific people, particularly the elderly, are more likely to die from or suffer severe COVID19 if they contract the disease. Others, such as frontline health workers or people who are incarcerated or experiencing homelessness, are much more likely to develop COVID-19 due, respectively, to their frequent contact with the virus or the likelihood of rapid spread if infection breaches their environment. Yet the less vulnerable populations of most rich countries, those much less likely to die from COVID-19, will be vaccinated before the most vulnerable in most poor countries. Hence, the most obvious consequence of vaccine inequity is that more people are likely to die. Furthermore, a lack of access to vaccination in certain countries will increase the ongoing rights limitations associated with COVID-19 restrictions including their grave civil, social and economic impacts. ${ }^{17}$

Even without a global humanistic argument for enhanced vaccine equity, there are global health and economic reasons why pursuit of equity makes sense. First, the emergence of SARS-CoV-2 "variants of concern" is related to the degree of virus circulating in a population; more infections means greater opportunities for variants to arise. Some variants can have increased transmission potential, higher fatality rate, and/or reduce vaccine

\footnotetext{
${ }^{16}$ See Mark Eccleston-Turner \& Harry Upton, International Collaboration to Ensure Equitable Access to Vaccines for COVID-19: The ACT-Accelerator and the COVAX Facility, Milbank Quarterly 1, 11 (Mar. 2, 2021) (on the effect of bilateral advance purchase orders on COVAX vaccine numbers). https://onlinelibrary.wiley.com/doi/full/10.1111/1468-0009.12503 See also Alexandra L. Phelan et al., Legal Agreements: Barriers and Enablers to Global Equitable COVID-19 Vaccine Access, 396 The Lancet 800 (2020). ${ }^{17}$ Sarah Joseph, International Human Rights Law and the Response to the COVID-19 Pandemic, 11 Int'I Humanitarian Legal Stud. 249 (2020).
} 
efficacy. ${ }^{18}$ Hence, continued high-level global infections equals ongoing potential for new variants of concern, which can compromise the protection offered by vaccines.

Second, although "vaccine passports" may enable many people, especially from rich countries, to travel internationally by the end of 2021, it seems likely that some travel constraints will remain, including requirements of possible quarantine on return from high COVID-19 prevalence settings.

Finally, the pandemic, including measures such as lockdown imposed necessarily to decelerate spread of the virus, has wreaked havoc on local and regional economies, and therefore the global economy. Global economic activity will be enhanced through greater COVID-19 control in all states, not just rich countries. Thus, global vaccine equity makes public health and economic sense for all states, rich and poor.

\section{Part 2: International Human Rights Law and Vaccine Inequity}

Under international human rights law, states have duties to respect, protect and fulfil the human rights of their populations. The duty to respect is a duty to refrain from directly or indirectly abusing human rights. The duty to protect requires states to take appropriate steps to prevent, investigate and punish adverse interferences with rights by third parties. The duty to fulfil requires states to adopt measures to facilitate, promote and provide for the enjoyment of the relevant right, especially for those unable to independently satisfy enjoyment of the right. ${ }^{19}$

Under Article 12(2)(c) of the International Covenant on Economic, Social and Cultural Rights (ICESCR), States Parties must 'take steps ... for ... prevention, treatment and control of epidemic ... and other diseases.' Hence, states must utilise their 'maximum available resources' (under the obligation provision, Article 2(1)) to gain access to and administer safe and effective vaccines. Given the deadly nature of COVID-19, the need to combat it is also required under the right to life in Article 6 of the International Covenant on Civil and Political Rights (ICCPR). These are not obligations of result but rather obligations of conduct. ${ }^{20}$ That is, states are required to exercise due diligence and do what can reasonably be expected to prevent COVID-19 infections and mitigate their impact, including the acquisition of vaccines, but it is recognised in the ICESCR that resource or other constraints may hinder and even prevent a state from accessing vaccines.

Once acquired, states have an obligation to roll out vaccines in a safe, effective and equitable manner, bearing in mind logistical constraints. Duties of equitable distribution of vaccines also arise under Article 15(1)(b) of the ICESCR, which recognises the rights of all to benefit from scientific progress and its applications. The equitable distribution of vaccines

\footnotetext{
${ }^{18}$ See World Health Organization, 'Tracking SARS-CoV-2 variants', https://www.who.int/en/activities/trackingSARS-CoV-2-variants/

${ }^{19}$ Sarah Joseph, Blame It on the WTO 22 (2011)

${ }^{20}$ Antonio Coco \& Talita de Souza Dias, Prevent, Respond, Cooperate: States' Due Diligence Duties Vis-á-Vis the COVID-19 Pandemic, 11 Int'I Humanitarian Legal Stud. 218 (2020).
} 
in-country means that the vaccine should be rolled out to the most vulnerable populations first, especially while supply outstrips demand. ${ }^{21}$

\section{Extraterritorial Obligations}

Having discussed the human rights obligations of states inside their territories, we turn to the subject of more relevance to our paper: extraterritorial obligations. States have extraterritorial human rights obligations to people in other states. Such duties stem from numerous sources, such as Articles 55 and 56 of the UN Charter. ${ }^{22}$

A joint statement by several UN human Special Rapporteurs, experts appointed to report on particular human rights issues, was released on 9 November $2020,{ }^{23}$ and recommended that states should:

Comply with their international obligations of ensuring access to medicines, including COVID-19 vaccines and treatment to all and of international assistance and cooperation. This [sic] by combatting the COVID-19 pandemic in a globally coordinated manner, including by joining the COVAX Global Vaccines Facility and putting aside misplaced individual initiatives to monopolize vaccine or supplies.

The experts clearly believe there is a duty under international human rights law to share vaccines, but they did not identify the precise sources of that duty. In this section, we will parse the sources of that duty, first by focusing on the ICCPR (due to the relevance of the right to life in Article 6) and then the ICESCR (due to the relevance of Articles 12 and 15(1)(b)).

The UN Human Rights Committee, the monitoring body which supervises implementation of the ICCPR, addressed the extraterritorial scope of the right to life in General Comment 36.24 It stated that a state is responsible for the rights to life of people in territories under their effective control, and of 'all persons over whose enjoyment of the right to life it exercises power or effective control' including those 'whose right to life is nonetheless impacted by its military or other activities in a direct and reasonably foreseeable manner'. ${ }^{25}$

\footnotetext{
${ }^{21}$ See WHO, WHO SAGE Values Framework for the Allocation and Prioritization of COVID-19 Vaccination, WHO: IRIS (Sept. 14, 2020), https://apps.who.int/iris/handle/10665/334299.

22 See generally Sarah Joseph \& Sam Dipnall, Scope of Application, in International Human Rights Law 110, at 120-130 (Daniel Moeckli et al. eds., 3rd ed. 2017).

${ }^{23}$ Off. of the U.N. High Comm'r for Hum. Rts., Statement by U.N. Human Rights Experts Universal Access to Vaccine is Essential for Prevention and Containment of COVID-19 Around the World (Nov. 9, 2020), https://www.ohchr.org/EN/NewsEvents/Pages/DisplayNews.aspx?NewsID=26484\&LangID=E. See also Off. of the U.N. High Comm'r for Hum. Rts., Human Rights and Access to COVID-19 Vaccines (Dec. 17, 2020), https://www.ohchr.org/Documents/Events/COVID-19_AccessVaccines_Guidance.pdf. ${ }^{24}$ U.N. Hum. Rts. Comm., General Comment No. 36: Art. 6 (Right to Life), U.N. Doc. CCPR/C/GC/35, (Sept. 3, 2019). General Comments are consensus statements issued by the UN human rights treaty bodies which elaborate upon particular aspects of the relevant treaty. Most General Comments constitute expanded interpretations of particular rights.

${ }^{25}$ U.N. Hum. Rts. Comm., General Comment No. 36: Art. 6 (Right to Life), U.N. Doc. CCPR/C/GC/35, at ๆ 63 (Sept. 3, 2019).
} 
The notion of 'territories under ... effective control' is relevant in cases of occupation, such as Israel regarding the Palestinian territories, ${ }^{26}$ Russia regarding Crimea, and the US regarding Guantanamo Bay and Guam. All of those states have obligations to the people of those subordinate territories, due to their effective control thereof, to provide them with vaccines and vaccination, just as they do to people within their own territories.

The reference to effective control over the right to life of a person has generally related to people who are in the custody of state agents. ${ }^{27}$ However, the formulation of the extraterritorial scope of the right to life in General Comment 36, adopted in 2019, is more expansive than earlier enunciations. ${ }^{28}$ It was applied in the twin cases of A.S $v$ Malta and A.S. $v$ Italy ${ }^{29}$ in the context of the extraterritorial responsibility of states for the lives of people who drowned after the respective states failed to save them when their vessel sank. While the case against Malta, in whose territorial waters the migrants' boat sank, was inadmissible for procedural reasons, the complaint against Italy was upheld. Italy was found to have breached the right to life by failing to exercise due diligence by promptly sending its navy ship, which was in close proximity to the sinking vessel, to rescue the migrants.

Despite the apparent increasing scope of ICCPR extraterritorial obligations, the jurisdictional link between a state which has procured vaccines for its own people, and people who might die of COVID-19 in another state that lacks vaccines, is more remote than that between Italy and the people who drowned. It is difficult at present to extrapolate a general duty under the ICCPR for a state to equitably share vaccines with other states, though such obligations could be evolving. Certain actions discussed below might fall within Article 6 , such as the deliberate blocking of a shipment of vaccines to another state. ${ }^{30}$

Extraterritorial obligations under the ICESCR seem broader than those under the ICCPR. Such obligations are alluded to explicitly in Article 2(1) thereof, which requires states parties to progressively realize ICESCR rights through steps taken individually 'and through international assistance and cooperation'. The International Court of Justice has confirmed that extraterritorial obligations exist under the ICESCR in Democratic Republic of Congo $\mathrm{v}$ Uganda, ${ }^{31}$ though it did not clarify their precise scope.

\footnotetext{
${ }^{26}$ See Eyal Benvenisti, Israel is Legally Obliged to Ensure the Population of the West Bank and Gaza Strip are Vaccinated, JUST SECURITY BLOG (Jan. 7, 2021), https://www.justsecurity.org/74091/israel-is-legally-obligated-toensure-the-population-in-the-west-bank-and-gaza-strip-are-vaccinated/ (while Israel has run an excellent vaccination program within Israel, it has failed in its international duties to provide vaccines to the Palestinian populations of the West Bank and Gaza.).

${ }^{27}$ See U.N. Hum. Rts. Comm, Communication on Lopez v Uruguay, UN doc. UN Doc CCPR/C/13/D/52/1979 (July 29, 1981).

${ }^{28}$ M. Milanovic, 'Drowning Migrants, the Human Rights Committee, and Extraterritorial Human Rights Obligations' (2021) EJIL: Talk!, 16 March 2021

${ }^{29}$ U.N. Hum. Rts. Comm., Communication on A.S. et al. v. Italy, U.N. Doc. CCPR/C/130/D/3042/2017 (May 19, 2017); U.N. Hum. Rts. Comm., Communication on A.S. et al. v. Malta, U.N. Doc. CCPR/C/130/D/3043/2017 (May 19, 2017).

${ }^{30}$ Note, however, that such actions might sometimes be justified. X-ref.

${ }^{31}$ Armed Activities on the Territory of the Congo (Democratic Republic of the Congo v Uganda) (Judgment, Merits) [2005] ICJ Rep 168, para 216.
} 
The Maastricht Principles on the Extraterritorial Obligations of States in the Area of Economic, Social and Cultural Rights (Principles) were adopted in 2011 by a group of legal experts under the auspices of Maastricht University and the International Commission of Jurists. ${ }^{32}$ Principle 9 states:

A State has obligations to respect, protect and fulfil economic, social and cultural rights in any of the following: ...

b) situations over which State acts or omissions bring about foreseeable effects on the enjoyment of economic, social and cultural rights, whether within or outside its territory ...

The Principles purport to explain existing international law. However, they are not of themselves binding, so they do not put an end to debate over the extraterritorial scope of the ICESCR.

Given that extraterritorial jurisdiction under the ICESCR exists, one may readily assume that states are required to respect ICESCR rights outside their borders. This is the negative duty to refrain from acts which cause or exacerbate human rights harms. This is reflected, in the context of COVID-19 vaccines, in the following comment from the WHO:

at a minimum, nation-states have an obligation in global equity not to undermine the ability of other states to meet their obligations to their own people to secure vaccines. $^{33}$

The Committee on Economic, Social, and Cultural Rights ('CESCR Committee'), the body which monitors and supervises implementation of the ICESCR, has confirmed on numerous occasions its belief that states parties also have duties to protect ICESCR rights in other states. ${ }^{34}$ As such duties are relevant in the context of states regulating private bodies, they are discussed below in relation to the human rights obligations of pharmaceutical companies. ${ }^{35}$

The most controversial aspect of potential extraterritorial duties under the ICESCR relates to fulfilling ICESCR rights in other states. Such a duty implies that rich states are obliged to provide aid to assist poorer countries. Rich states predictably resist such a characterization of their ICESCR duties. Yet such a duty is evident in the words of the Declaration on the Right

\footnotetext{
${ }^{32}$ Maastricht Principles on the Extraterritorial Obligations of States in the Area of Economic, Social and Cultural Rights, https://www.etoconsortium.org/nc/en/main-navigation/library/maastrichtprinciples/?tx drblob pi1\%5BdownloadUid\%5D=23, January 2013 [hereinafter Maastricht Guidelines].

${ }^{33}$ WHO, WHO SAGE Values Framework for the Allocation and Prioritization of COVID-19 Vaccination, WHO: IRIS, 7 (Sept. 14, 2020), https://apps.who.int/iris/handle/10665/334299.

${ }^{34}$ See, eg, CESCR, General Comment 15, HRI/GEN/1/Rev.9 (Vol 1) 97, para 33. See also CESCR, General Comment 19, HRI/GEN/1/Rev.9 (Vol 1) 152, para 54; Comm. on Econ., Soc. \& Cultural Rts., General Comment No. 24 on State Obligations Under the International Covenant on Civil and Political Rights in the Context of Business Activities, U.N. Doc. E/C. 12/GC/24, Part C (Aug. 10, 2017)

${ }^{35} \mathrm{X}$-ref.
} 
to Development, ${ }^{36}$ as well as the 2030 Agenda for Sustainable Development. ${ }^{37}$ The CESCR Committee has indicated that states have a duty to assist other states to provide international assistance with regard to the enjoyment of ICESCR rights when they are in a position to do so. ${ }^{38}$

The obligation to fulfil ICESCR rights is a positive obligation to take action rather than the simpler negative obligation to refrain from action. As stated above, it can be split into obligations to facilitate, promote and provide for such rights. Facilitation of a right is to help to provide an enabling environment for its exercise. Promotion is to raise awareness of a right. 'Providing' is to directly provide for the enjoyment of rights by a person who is unable to otherwise enjoy them. ${ }^{39}$ The obligation to provide is the most onerous of the three, with the obligation to promote being the least onerous. Of particular relevance regarding COVID19 vaccines are the duties to facilitate and to provide.

Long before COVID-19, Margot Salomon wrote compellingly on obligations for rich states to share resources with poor states, particularly in relation to the ICESCR. One reason for her thesis is that "the problem of world poverty is not one of scarcity but of [vastly] unequal distribution". ${ }^{40} \mathrm{~A}$ duty to more equitably share global wealth and resources is also justified if one accepts that poverty is in large part exacerbated, and even caused, by a global economic order created by developed states in favour of developed states, ${ }^{41}$ that is that poverty is "done" by the rich to the poor. ${ }^{42}$ Indeed, philosopher Thomas Pogge has argued that long-term tolerance of an inequitable system, which has led to gross global inequality and mass poverty, is a failure in negative duties to respect rather than positive duties to fulfil. ${ }^{43}$ Arguments regarding an unfair global economic order, which has itself contributed to the present situation of vaccine inequity, are revisited below towards the end of Part 3.

We concede that aspects of extraterritorial duties remain controversial, particularly duties to protect (discussed further below) and fulfil. The legal position is muddied because statements by treaty bodies like the CESCR Committee, and by Special Rapporteurs, are not binding at international law. However, we contend, in concordance with the CESCR Committee and the Maastricht Principles, that such duties exist. As noted by Matthew Craven, a denial of positive ICESCR extraterritorial duties would deprive the poorest and most marginalised, those with the greatest need for ICESCR rights recognition, of meaningful avenues of redress: have-nots would have no claim against the haves, who are

\footnotetext{
${ }^{36}$ Declaration on the Right to Development, esp Art 4.

37 UNGA Resolution A/Res/70/1: Transforming our world: the 2030 Agenda for Sustainable Development, (21 October 2015

${ }^{38}$ Eg CESCR, General Comment 3, HRI/GEN/1/Rev.9 (Vol 1) 7, para 14; CESCR General Comment 12, n 60, para 35; CESCR General Comment 15, n 108, para 38; GC 134, paras 38-40.

${ }^{39}$ Sarah Joseph, Blame It on the WTO 22 (2011).

${ }^{40}$ Margot E. Salomon, Why Should It Matter That Others Have More? Poverty, Inequality, and the Potential of International Human Rights Law, 37 Rev. of Int'I Stud. 2137, at 2145 (2011).

${ }^{41}$ Thomas Pogge, Recognised and Violated by International Law: The Human Rights of the Global Poor, 18 Leiden J. of Int'I L. 717 (2005).

42 Susan Marks, Human Rights and the Bottom Billion, 1 Eur. Hum. Rts. L. Rev. 37, 48 (2009).

${ }^{43}$ Thomas Pogge, Severe Poverty as a Violation of Negative Duties 19 Ethics and International Affairs 55, 68 (2005).
} 
plainly in the best position to assist: there would be a 'disjunction between the proclamation of rights ... and the contingent conditions for their fulfilment' ${ }^{4}{ }^{4}$

Furthermore, the contrast between negative duties to respect and positive duties to fulfil is occasionally blurred. As noted several times below, it is sometimes possible to classify a state's action as a failure to take appropriate positive action to enhance human rights and, simultaneously, an action which negatively interferes with another state's ability to fulfil its own human rights obligations. ${ }^{45}$

While both Covenants have over 170 states parties, not all states are party to both of them. Notable absentees include the US from the ICESCR, and China from the ICCPR. This fact enhances the importance of the customary scope of extraterritorial human rights duties. However, such duties are beyond the scope of this paper, apart from in one aspect discussed below. ${ }^{46}$ That is because it is very unlikely that the extraterritorial scope of customary duties with regard to civil and political rights, and economic social and cultural rights, extends beyond the scope of extraterritorial duties under the respective Covenants. ${ }^{47}$

Finally, the dichotomy between intra-territorial and extraterritorial obligations is not as stark as might be thought. As noted above, it is in the interests of a state's own population for the pandemic to be extinguished, both inside and outside territory. A pandemic poses a continued threat to the people inside a state, even if that state has managed to tame the pandemic within its borders. As the WHO has stated:

Infectious threats to health know no borders; as long as there is active SARS-CoV-2 transmission anywhere there will be a risk of transmission everywhere. Moreover, protecting the public health of one's residents is not the only national interest countries have in containing the pandemic globally. The recovery of national economies also depends on securing stable global supply chains and global markets and regularizing international travel, which will not be possible until the pandemic is contained globally. Hence the equitable allocation of vaccines globally is in all countries' enlightened self-interest. ${ }^{48}$

Thus, there is a strong argument that a state has obligations to its own people to do what it can reasonably do to facilitate and provide for increased vaccinations all over the world, so as to enhance rights to life and health, as well as rights associated with greater travel and global economic opportunities. ${ }^{49}$

\footnotetext{
${ }^{44}$ Matthew Craven, The Violence of Dispossession: Extraterritoriality and Economic, Social and Cultural Rights, in Economic, Social and Cultural Rights in Action 83 (Mashood Baderin and Robert McCorquodale eds, 2007). 
Let us now turn to look at the human rights compatibility of specific actions with regard to COVID-19 vaccines.

\section{Embargoes on Vaccines and Raw Materials}

If a state is actively blocking access by another state to the vaccine, that might entail a failure to respect rights in the latter state by interfering with the latter state's ability to secure vaccines for its people. Regarding embargos, the CESCR Committee has stated in General Comment 14 on the right to health:

States parties should refrain at all times from imposing embargoes or similar measures restricting the supply of another State with adequate medicines and medical equipment. Restrictions on such goods should never be used as an instrument of political and economic pressure. ${ }^{50}$

Of relevance could be pre-existing US economic embargoes on Iran and Cuba, which might limit their access to vaccines. Indeed, those embargoes have prompted cooperation between those countries in jointly developing a vaccine. ${ }^{51}$

There have been examples of states blocking the export of COVID-19 vaccines to other states. In March 2021, Italy blocked a shipment of the AstraZeneca vaccine to Australia, entailing a direct interference in the access by Australians to that vaccine. In April 2021, the United States ('US') refused a request by India for access to raw materials for the manufacture of vaccines.

An export block, directly interfering in a commercial arrangement between the exporter and the intended importing state, probably breaches extraterritorial duties to respect human rights if the blocking state has a low case load. However, in both instances cited above, the blocking of export was said to be due to the need for the blocking entity, respectively Italy and the US, to ensure vaccine access for its own people. For example, Italy's stated reason for blocking export to Australia was that AstraZeneca had failed to fulfil its contractual obligations to deliver vaccines to the EU, and that the bloc's need for the vaccines was plainly greater than that of Australia. ${ }^{52}$ In denying India's request for vaccine raw materials in April 2021, a US State Department spokesperson referred to the need for the US to prioritise bringing down its own large case load. ${ }^{53}$

\footnotetext{
${ }^{50}$ Comm. on Econ., Soc. \& Cultural Rts., General Comment No. 8: The Relationship Between Economic Sanctions and Respect for Economic, Social and Cultural Rights, U.N. Doc. E/C. 12/1997/8 (Dec. 12, 1997), para 41. See also Maastricht Guidelines, art. 22.

${ }^{51}$ Natalie Dare, Hit by US Sanctions, Cuba and Iran Join Hands to Secure COVID-19 Vaccine, TRT World (Mar. 9, 2021), https://www.trtworld.com/magazine/hit-by-us-sanctions-cuba-and-iran-join-hands-to-secure-covid-19vaccine-44857.

52 Italy, EU Refuse AstraZeneca Request to Ship 250,000 Doses of Vaccine to Australia, ABC News (Mar. 5, 2021, 3:05 PM), https://www.abc.net.au/news/2021-03-05/italy-eu-block-250000-astrazeneca-doses-toaustralia/13218348.

53 U.S. Defends Restrictions on Export of COVID-19 Vaccine Raw Materials Amid India's Request to Lift Ban, The Hindu (Apr. 23, 2021, 1:29 PM), https://www.thehindu.com/news/international/us-defends-restrictions-onexport-of-covid-19-vaccine-raw-materials-amid-indias-request-to-lift-ban/article34391251.ece.
} 
Thus, the actions of Italy and the US were prompted by their prioritisation of vaccine access of their own populations over those in, respectively, Australia and India. They were prioritising fulfilment of their national human rights obligations over extraterritorial ones. The permissibility of such action under international human rights law is discussed directly below, in the context of the national procurement of vaccines.

\section{Jumping Vaccine Queues and Hoarding}

At present, developed states have scooped up most available vaccines for now and the near future pursuant to Advance Purchase Agreements with vaccine manufacturers. ${ }^{54}$ The procurement of vaccines for national use by states directly interferes with vaccine access by the people of other countries while demand outstrips supply, so perhaps it could be viewed as a breach of the duty to respect human rights extraterritorially. The CESCR Committee thinks so, in a statement issued on 23 April 2021:

Given the global nature of the pandemic, States have the obligation to support, to the maximum of their available resources, efforts to make vaccines available globally. Vaccine nationalism breaches the extraterritorial obligations of States to avoid taking decisions that limit the ability of other States to make vaccines available to their populations and thus to implement their human rights obligations relating to the right to health, as it results in a shortage of vaccines for those who are most in need in the least developed countries. ${ }^{55}$

However, while national procurement reduces the pool of available vaccines (while scarcity prevails), it also fulfils a state's obligations to its own people regarding the right to health. How is a state meant to balance its internal and external human rights duties? According to the CESCR Committee:

Prioritization in the global, and indeed the national, distribution of vaccines should be based on medical needs and public health considerations. ${ }^{56}$

Thus, the CESCR Committee believes that vaccine accessibility for vulnerable populations abroad must be prioritised over less vulnerable populations at home ${ }^{57}$ Essentially, the

\footnotetext{
${ }^{54}$ Alexandra L. Phelan et al., Legal Agreements: Barriers and Enablers to Global Equitable COVID-19 Vaccine Access, 396 The Lancet 800 (2020).

${ }^{55}$ Statement by the Committee on Economic, Social and Cultural Rights, 'Statement on universal affordable vaccination against coronavirus disease (COVID-19), international cooperation and intellectual property', UN doc E/C.12/2021/1, 23 April 2021, para 4.

${ }^{56}$ Statement by the Committee on Economic, Social and Cultural Rights, 'Statement on universal affordable vaccination against coronavirus disease (COVID-19), international cooperation and intellectual property', UN doc E/C.12/2021/1, 23 April 2021, para 5.

57 See also Ezekiel J. Emanuel et al., How Many Vaccine Doses Can Nations Ethically Hoard?: The Case for Sharing Supplies Prior to Reaching Herd Immunity, Foreign Affairs (Mar. 9, 2021), https://protectau.mimecast.com/s/HovXCoVzpvfrxNWZOH1DsK9?domain=foreignaffairs.com; Alexandra L. Phelan et al., Legal Agreements: Barriers and Enablers to Global Equitable COVID-19 Vaccine Access, 396 The Lancet 800, at 801 (2020).
} 
Committee believes that distribution should take place largely if not exclusively through the COVAX facility. ${ }^{58}$

Such a strategy would delay vaccines for most younger people until at least 2022. Yet while younger people are at lesser risk of severe outcomes from COVID-19, they can still die or suffer grave health issues, and have also borne a great economic and social burden in this pandemic. Furthermore, the terms of the COVAX facility do not ban separate bilateral deals with vaccine manufacturers: their existence is conceded by Gavi in its COVAX explainer. ${ }^{59}$ It is difficult to claim that COVAX must govern vaccine allocations to the exclusion of bilateral deals when that is not what was actually agreed.

The UN Special Rapporteurs, in their 2020 statement, argued that vaccine nationalism prejudices the interests of a state's own people:

In addition, epidemiologists and others fear that, because of the limited capacity of production of the vaccine, countries that are striking deals to secure vaccines for their own population - instead of engaging in a coordinated global effort to share them across borders - will not achieve their intended purpose. The pandemic will continue and will come back to impact those countries sooner or later, including through further economic disruption. A message, often repeated in 2020, remains essential: No one is secure until all of us are secure. ${ }^{60}$

This instrumentalist argument provides a human rights justification for states to prioritise vaccines for more vulnerable people in other countries compared to vaccines for their own, less vulnerable, people. Such a trade-off would not breach a state's intra-territorial human rights duties to its own people. Furthermore, it is indeed arguable that the long-term interests of a state's population are enhanced by more globally equitable vaccine access.

Any duty to prioritise extraterritorial obligations regarding vaccine access over the parallel internal obligations likely crystallises only after a significant part of its own population has been vaccinated, and grows stronger from that point. That point may not be as high as the level needed to prevent ongoing spread, but is probably high enough to considerably reduce the disease burden of COVID-19 within a state.

Some states have ordered enough vaccines to vaccinate their populations many times over. ${ }^{61}$ Over-ordering has been caused, at least in part, by nations ordering vaccines during the trial phase without knowing which ones would succeed. There is a difference between over-ordering and the hoarding of vaccines. In that respect, it was thoroughly appropriate

\footnotetext{
${ }^{58}$ Statement by the Committee on Economic, Social and Cultural Rights, 'Statement on universal affordable vaccination against coronavirus disease (COVID-19), international cooperation and intellectual property', UN doc E/C.12/2021/1, 23 April 2021, para 6.

59 https://www.gavi.org/vaccineswork/covax-explained

${ }^{60}$ Off. of the U.N. High Comm'r for Hum. Rts., Statement by U.N. Human Rights Experts Universal Access to Vaccine is Essential for Prevention and Containment of COVID-19 Around the World (Nov. 9, 2020), https://www.ohchr.org/EN/NewsEvents/Pages/DisplayNews.aspx?NewsID=26484\&LangID=E.

${ }^{61}$ Off. of the U.N. High Comm'r for Hum. Rts., Human Rights and Access to COVID-19 Vaccines, 2 (Dec. 17, 2020), https://www.ohchr.org/Documents/Events/COVID-19_AccessVaccines_Guidance.pdf (see point 3).
} 
for the US to release its AstraZeneca supplies to other States once it became clear that it was unlikely to need or even use them. ${ }^{62}$

The hoarding of scarce vaccines after the vaccination of one's population would constitute a breach of a duty to share in a vital scarce resource that can enhance enjoyment of the rights to health and life in other countries. The rights of a state's own people are also harmed if a state hoards vaccines, thus helping to delay the end of the pandemic, while vaccine scarcity prevails. Thus, hoarding may breach a State's intra-territorial human rights duties too.

\section{Vaccine Aid}

Vaccine aid is a means by which to comply with the extraterritorial duty to fulfil ICESCR rights in its most onerous form: providing for rights. Vaccine aid is being delivered, including by funding commitments to COVAX and through bilateral arrangements. Of even more use than money are actual donations of vaccines. As stated by WHO Director-General Dr Tedros: 'if there are no vaccines to buy, money is irrelevant' ${ }^{63}$ In that regard, Australia has sent vaccines to Papua New Guinea, ${ }^{64}$ while New Zealand became the first state to donate vaccines to COVAX, rather than money, in April 2021. ${ }^{65}$ In June 2021, the US announced that it would donate 500 million Pfizer doses, purchased at low cost, to COVAX. ${ }^{66}$ The G7 pledged one billion doses in June 2021, some to be distributed directly and others through COVAX. These pledges are welcome but not enough, according to the WHO and the International Monetary Fund ('IMF'). ${ }^{67}$

Conditional aid cannot be classified as bona fide compliance with any obligation to extraterritorially fulfil human rights. Many states are desperate to access vaccines for their people, so it is difficult to refuse conditional vaccine aid. Conditions may be acceptable if they relate to the safe, efficient and equitable rollout of the vaccine. However, there were reports in late March 2021 of China attaching conditions regarding unrelated economic opportunities to its vaccine aid in the Pacific and Latin America, for example regarding access by Chinese company Huawei to tenders to build local $5 G$ network infrastructure ${ }^{68}$ If true, such demands could arguably be classified as an interference in the rights of selfdetermination of the relevant populations, with key policy decisions being forcibly removed

\footnotetext{
62 Anthony Zurcher, 'AstraZeneca: US to share up to 60m vaccine doses', BBC, 26 April, https://www.bbc.com/news/world-us-canada-56893701

63.WHO (@WHO), Twitter (Feb. 23, 2021, 1:16 AM), https://twitter.com/WHO/status/1363870364657475586?s=20.

${ }^{64}$ Anthony Galloway, Australia to Send Tens of Thousands of Vaccines to PNG and East Timor, The Sydney Morning Herald (Apr. 9, 2021, 5:39 PM), https://www.smh.com.au/politics/federal/australia-to-send-tens-ofthousands-of-vaccines-to-png-and-east-timor-20210409-p57hyh.html.

65 Jason Walls, NZ Donates 1.6 Million Vaccine Doses, Adern Calls for 'Team of 7.8 Billion', The New Zealand Herald (Apr. 16, 2021, 3:37 PM), https://www.nzherald.co.nz/nz/covid-19-coronavirus-nz-donates-16-millionvaccine-doses-ardern-calls-for-team-of-78-billion/HJA6IS3B6Z7RKNSEHBTRTTNCFY/.

${ }^{66}$ Nancy Cordes et al, 'Biden administration buys 500 million Pfizer COVID-19 vaccine doses for global use', CBS News, 10 June 2021.

67 'G7 COVID-19 vaccine pledge 'is not enough', says WHO, IMF', Euronews, 13 June 2021.

${ }^{68}$ Geoff Chambers \& Ben Packham, China 'Vax-Mail' to Swap Jabs for Access, The Australian (Mar. 24, 2021), https://www.theaustralian.com.au/nation/politics/china-vaxmail-to-swap-jabs-for-access/newsstory/21478d2f8c907fab9efabde82f4c4e5a (note that conditional aid is not new nor is it unique to China).
} 
from their hands and the hands of their government. ${ }^{69}$ The right of self-determination is recognised, uniquely, in Article 1 of both Covenants.

Vaccine aid is important, and we endorse the idea that such donations are a duty rather than mere beneficence on the part of donors. But a more crucial aspect of the duty to fulfil is for states to do what they can to increase the number of vaccines in the world so that supply can more swiftly match demand. Just as importantly, states must do what they reasonably can to facilitate COVID-19 vaccine access by removing barriers to such an increase. Finally, states must not themselves erect or keep barriers to such an increase in place, which would arguably breach duties to respect rather than duties to fulfil. This issue is taken up below in Part 3.

\section{Human Rights Duties of Pharmaceutical Companies}

To conclude Part 2, we detour from the discussion of state obligations under international human rights law to focus on the entities that own the vaccines, pharmaceutical companies. The orthodox view is that private bodies do not have direct obligations under international human rights law, except, perhaps, with regard to the most extreme abuses which constitute international crimes: genocide, crimes against humanity and grave war crimes. ${ }^{70}$

Concern over business-related human rights abuses, generated by the great power and multijurisdictional nature of multinational corporations, led in 2011 to the adoption by the UN of the UN Guiding Principles on Business and Human Rights ('UNGPs'). ${ }^{71}$ One 'pillar' of these Principles is the enunciation of a corporate responsibility to respect human rights. This is not a legally binding duty but rather one sourced in societal expectations, which demands that businesses identify and address their adverse impacts on human rights. ${ }^{72}$ The acceptance of this 'responsibility' has been widely embraced by businesses, at least rhetorically. ${ }^{73}$

Some of these ideas have been echoed specifically regarding COVID-19 vaccines. The UN Special Rapporteurs stated that pharmaceutical companies should:

Discharge their responsibilities, including by exercising human rights due diligence to identify and address adverse impacts on the rights to life and health as set out in the Guiding Principles on Business and Human Rights. In particular, they should refrain

\footnotetext{
${ }^{69}$ See, e.g., Christopher Kilby, Aid and Sovereignty, 25 Soc. Theory and Prac. 79 (1999) (extensive discussion of this point is beyond the scope of this paper).

${ }^{70}$ See, e.g., Joanna Kyriakakis, Corporations, Accountability and International Criminal Law: Industry and Atrocity (Edward Elgar Publ'g 2022) (manuscript ch. 6).

${ }^{71}$ UN HRC, 'Report of the Special Representative of the Secretary-General on the issue of human rights and transnational corporations and other business enterprises, John Ruggie, Guiding Principles on Business and Human Rights: Implementing the United Nations "Protect, Respect and Remedy" Framework' (21 March 2011) UN Doc A/HRC/17/31 <https://www.ohchr.org/Documents/Issues/Business/A-HRC-17-31 AEV.pdf.

72 G.A. Res. A/HRC/8, q 54 (Apr. 7, 2008).

73 Their actual compliance with these responsibilities may be criticised.
} 
from causing or contributing to adverse impacts on the rights to life and health by invoking their intellectual property rights and prioritizing economic gains. ${ }^{74}$

Intellectual property is discussed in detail below in Part 3. Similar ideas were extrapolated earlier and further in 2008, when the then Special Rapporteur on the Right to Health, Paul Hunt, published the Human Rights Guidelines for Pharmaceutical Companies in relation to Access to Medicines. ${ }^{75}$

Some pharmaceutical companies have arguably abided by these responsibilities.

AstraZeneca has said it will work to license the manufacture of its vaccine across the world at no profit. ${ }^{76}$ Moderna has promised not to enforce its patent. ${ }^{77}$ Pfizer, on the other hand, seems to be taking full commercial advantage of its monopoly control of its vaccines. ${ }^{78}$ An April 2021 deal with the European Union involved a 50\% price rise from a previous deal, according to the Prime Minister of Bulgaria. ${ }^{79}$ Israel's early access to Pfizer was facilitated by its willingness to pay a high price, ${ }^{80}$ and to share the disaggregated anonymised data of its vaccinated people with the company. ${ }^{81}$ Pfizer has been criticised by Latin American

\footnotetext{
74 Off. of the U.N. High Comm'r for Hum. Rts., Statement by U.N. Human Rights Experts Universal Access to Vaccine is Essential for Prevention and Containment of COVID-19 Around the World (Nov. 9, 2020), https://www.ohchr.org/EN/NewsEvents/Pages/DisplayNews.aspx?NewsID=26484\&LangID=E.

${ }^{75}$ Rep. of Paul Hunt (Special Rapporteur) on the Right of Everyone to the Enjoyment of the Highest Attainable Standard of Physical and Mental Health, U.N. Doc. A/63/263, annex (Aug. 11, 2008) [hereinafter Paul Hunt Report]. See also Michael Santoro \& Robert Shanklin, Human Rights Obligations of Drug Companies, 19 J. of Hum. Rts. 557 (2020).

${ }^{76}$ AstraZeneca, AstraZeneca Takes Next Steps Towards Broad and Equitable Access to Oxford University's Potential COVID-19 Vaccine, AstraZeneca: Media (June 4, 2020), https://www.astrazeneca.com/mediacentre/articles/2020/astrazeneca-takes-next-steps-towards-broad-and-equitable-access-to-oxford-universityspotential-covid-19-vaccine.html. Note, however, that AstraZeneca has reserved a right to declare an end to the pandemic, and thus charge higher costs, as soon as July 2021

${ }^{77}$ Reuters, Moderna will Not Enforce COVID-19 Vaccine Patents During Pandemic, Reuters (Oct. 8, 2020, 9:46 PM), https://www.reuters.com/article/health-coronavirus-moderna-idUSL4N2GZ2D6 (however, one may note that Moderna's patent is enforceable, while its statement is not. Furthermore, one may note that the there are multiple patents in that vaccine that are not owned by Moderna: Rebecca Robbins \& Peter S. Goodman, Pfizer Reaps Hundreds of Millions in Profits from COVID Vaccine, The New York Times (May 4, 2021), https://www.nytimes.com/2021/05/04/business/pfizer-covid-vaccine-profits.html).

${ }^{78}$ Rebecca Robbins \& Peter S. Goodman, Pfizer Reaps Hundreds of Millions in Profits from COVID Vaccine, The New York Times (May 4, 2021), https://www.nytimes.com/2021/05/04/business/pfizer-covid-vaccineprofits.html.

${ }^{79}$ Bulgarian PM Reveals Price for EU's New Vaccine Contract with Pfizer, Reuters (Apr. 12, 2021, 11:10 PM), https://www.reuters.com/world/europe/bulgarian-pm-reveals-price-eus-new-vaccine-contract-with-pfizer2021-04-12/.

${ }^{80}$ Ari Rabinovitch et al., Pizza-Sized Boxes and Paying a Premium: Israel's COVID-19 Vaccine Rollout, Reuters (Jan. 6, 2021, 4:08 PM), https://www.reuters.com/article/us-health-coronavirus-israel-vaccinationidUKKBN29B0KJ.

${ }^{81}$ Aditya Goenka, Israel's Vaccine Rollout has been Fast So Why Is It Controversial and What Can Other Countries Learn?, The Conversation (Jan. 28, 2021, 1:40 AM), https://theconversation.com/israels-vaccinerollout-has-been-fast-so-why-is-it-controversial-and-what-can-other-countries-learn-153687.
} 
countries for making unreasonable demands regarding collateral guarantees for any future legal cases, ${ }^{82}$ as well as extensive unusual indemnities. ${ }^{83}$

Despite international (and national) developments regarding business and human rights, the primary duty-bearers under international human rights law remain states. States are required to exercise due diligence to protect their people from rights abuses by third parties, so that duty entails appropriate regulation of the private sector. Hence, states are required to take reasonable measures to protect people from rights abuses by pharmaceutical companies.

The scope and even the existence of an extraterritorial duty to protect is contentious. Its existence was denied in the commentary to the UNGPs, ${ }^{84}$ but it has been repeatedly confirmed by the CESCR Committee and the Maastricht Principles. ${ }^{85}$

The main way that a state could protect people from pharmaceutical companies with regard to vaccine access, both inside and outside territory, is to remove barriers that the companies pose in relation to access. This duty would dovetail with those mentioned at the conclusion of the previous section (that is, duties to remove barriers to vaccine access). That duty can be conceptualised as part of the contentious extraterritorial duty to protect, but it might also be conceptualised as an intra-territorial duty to protect people inside a state's territory, a duty which definitely exists under international human rights law.

At the international level, one potential blockage to greater access has attracted particular attention: the intellectual property (IP) rights afforded to pharmaceutical companies under the Agreement on Trade Related Aspects of Intellectual Property ("TRIPS") under the auspices of the World Trade Organisation ("WTO"). It is to those rights, and their interaction with international human rights law, that we now turn.

\footnotetext{
82 Madlen Davies et al., 'Held to Ransom': Pfizer Demands Governments Gamble With State Assets to Secure Vaccine Deal, The Bureau of Investigative Journalism (Feb. 23, 2021), https://www.thebureauinvestigates.com/stories/2021-02-23/held-to-ransom-pfizer-demands-governmentsgamble-with-state-assets-to-secure-vaccine-deal.

${ }^{83}$ See also Madlen Davies \& Rosa Furneaux, Vaccine Contract Forces Government to Pay If Pfizer Makes Mistakes, The Bureau of Investigative Journalism (Mar. 10, 2021), https://www.thebureauinvestigates.com/stories/2021-03-10/vaccine-contract-forces-dominican-republicgovernment-to-pay-if-pfizer-makes-mistakes (similar demands were apparently also made of South Africa before Pfizer "backed down": Madlen Davies \& Rosa Furneaux, Pfizer Backs Down Over 'Unreasonable' Terms in South Africa Vaccine Deal, The Bureau of Investigative Journalism (Apr. 19, 2021),

https://www.thebureauinvestigates.com/stories/2021-04-19/pfizer-backs-down-over-asset-seizing-clause-insouth-africa-vaccine-deal).

${ }^{84}$ Off. of the U.N. High Comm'r for Hum. Rts., Rep. on Implementing the U.N. 'Protect, Respect and Remedy' Framework, U.N. Doc. HR/PUB/11/04, at 3 (2011) (see Commentary to no. 2).

85 See Comm. on Econ., Soc. \& Cultural Rts., General Comment No. 24 on State Obligations Under the International Covenant on Civil and Political Rights in the Context of Business Activities, U.N. Doc. E/C. 12/GC/24, ๆ 20-35 (Aug. 10, 2017); Comm. on Econ., Soc. \& Cultural Rts., General Comment No. 25 (2020) on Science and Economic, Social and Cultural Rights, U.N. Doc. E/C. 12/GC/25, ๆ 83-84 (Apr. 30, 2020); Comm. on Econ., Soc. \& Cultural Rts., General Comment No. 23 (2016) on the Right to Just and Favourable Conditions of Work, U.N. Doc. E/C. 12/GC/23, ๆ 69-70 (Apr. 27, 2016); Comm. on Econ., Soc. \& Cultural Rts. See generally Maastricht Guidelines.
} 


\section{Part 3: Intellectual Property, COVID-19 Vaccines and Human Rights}

Under the Agreement on Trade Related Aspects of Intellectual Property ("TRIPS"), WTO Members are required to protect IP rights, such as copyright, patents and trademarks. Of most relevance to vaccine equity are the provisions regarding patents: Article 33 demands patent protection of twenty years. The Least Developed Countries ('LDCs') do not have to fully comply with TRIPS until 1 July 2021, ${ }^{86}$ nor do they have to protect pharmaceutical products with patents until $2033 .{ }^{87}$ The rationale for IP rights, as discussed below, is that they provide appropriate rewards to innovators and thus encourage and foster research and development.

Compulsory patent protection for pharmaceutical products provides for monopoly rights to patent-holders, which can restrict access thereto. In this way, TRIPS and IP rights may prejudice the rights in Articles 12 and 15(1)(b) of the ICESCR. As stated by the CESCR Committee in General Comment 25 on Article 15:

Patents give patent holders a temporary exclusive right to exploit the product or service they have invented. Thus, they can determine a price for these products and services. If prices are set very high, access to these products and services becomes impossible for low-income persons or developing countries as has happened with new medicines that are essential for the health and life of persons with certain diseases. ${ }^{88}$

Hence, the patent protection mandated by TRIPS might pose a barrier to access to medicines, including COVID-19 vaccines. In this regard, the Office of the UN High Commissioner for Human Rights ('OHCHR') stated at paragraph 6 of a guidance note on "Human Rights and COVID-19 Vaccines": 89

Intellectual property rights should not be applied in a manner which undermines the rights to health, food, science and other human rights. Obligations under the Agreement on [TRIPS], for example, should be interpreted consistently with the protection of public health ...

States have a duty to prevent unreasonably high costs for access to essential medicines and vaccines. To that end, they should take steps to protect the primacy of public health over private profit in line with their commitments to support research and development of vaccines and medicines, as well as preventative measures and treatments for communicable diseases, especially those that disproportionately impact developing countries.

TRIPS is binding on members of the WTO. In that respect, the Maastricht Principles state at Principle 15:

\footnotetext{
${ }^{86}$ LDCs have submitted a request for a further extension, which had not been decided upon at the time of writing. It seems likely to be granted.

${ }^{87}$ However, many LDCs have in fact adopted IP protection in advance of these dates. Rollback of IP protection is not permitted (though it is uncertain whether it might be permitted for pharmaceutical patents).

${ }^{88}$ Comm. on Econ., Soc. \& Cultural Rts., General Comment No. 25 (2020) on Science and Economic, Social and Cultural Rights, U.N. Doc. E/C. 12/GC/25, ๆ 61 (Apr. 30, 2020).

${ }^{89}$ https://www.ohchr.org/Documents/Events/COVID-19 AccessVaccines Guidance.pdf, 17 December 2020
} 
As a member of an international organisation, the State remains responsible for its own conduct in relation to its human rights obligations within its territory and extraterritorially. A State that transfers competences to, or participates in, an international organisation must take all reasonable steps to ensure that the relevant organisation acts consistently with the international human rights obligations of that State.

Similar sentiments are expressed by the CESCR Committee in its General Comments 14 (on Article 12$)^{90}$ and 25 (on Article 15). ${ }^{91}$ Duties regarding a state's own behaviour within an international organisation may be classified as duties to fulfil extraterritorial rights by facilitating appropriate actions by an international organisation. However, they might also on occasion entail duties to respect if a state's behaviour within an international organisation impairs, or contributes to the impairment of, the ability of another state to comply with its human rights obligations. Such behaviour is classified as 'indirect interference' within extraterritorial duties to respect in Article 21 of the Maastricht Guidelines.

Hence, states have human rights obligations with regard to their behaviour, actions, and votes within international organisations. Is there a human rights obligation to loosen TRIPS requirements to facilitate greater access to COVID-19 vaccines?

On 2 October 2020, South Africa and India sent a communication to the TRIPS Council of the WTO arguing for a waiver of certain parts of the TRIPS agreement 'until widespread vaccination is in place globally, and the majority of the world's population has developed immunity'. ${ }^{92}$ That initiative has been supported by most developing states and was initially resisted by developed states in the WTO.

However, on 5 May 2021, the Biden administration in the US announced that it would support a waiver of IP protections for COVID-19 vaccines, in light of the 'extraordinary' COVID-19 pandemic. There may be devil yet in the detail, with the US Trade Representative stating that:

We will actively participate in text-based negotiations at the [WTO] needed to make [the waiver] happen. Those negotiations will take time given the consensus-based nature of the institution and the complexity of the issues involved. ${ }^{93}$

The reference to delays in the negotiations is concerning, given the need for speed in manufacturing and distributing new vaccines. Furthermore, WTO decisions are made by

\footnotetext{
${ }^{90}$ Comm. on Econ., Soc. \& Cultural Rts., General Comment No. 14: The Right to the Highest Attainable Standard of Health (Art. 12), U.N. Doc. E/C. 12/2000/4, at ๆ 39 (Aug. 11, 2000).

${ }^{91}$ Comm. on Econ., Soc. \& Cultural Rts., General Comment No. 14: The Right to the Highest Attainable Standard of Health (Art. 12), U.N. Doc. E/C. 12/2000/4, at 983 (Aug. 11, 2000).

92 Council for Trade-Related Aspects of Intellectual Property Rights, Communication from India and South Africa: Waiver from Certain Provisions of the TRIPS Agreement for the Prevention, Containment and Treatment of COVID-19, WTO Doc. IP/C/W/669 (Oct. 2, 2020).

${ }^{93}$ Off. of the U.S. Trade Rep., Statement from Ambassador Katherine Tai on the COVID-19 TRIPS Waiver (May $5,2021)$.
} 
consensus. Other states, particularly from the EU, may continue to block waiver negotiations. ${ }^{94}$ Finally, the announcement indicates that the US supports a waiver, rather than the waiver as outlined in the South Africa/India proposal. For example, it is limited only to vaccines, rather than broader medical developments designed to combat COVID-19.

The waiver has been strongly supported by the CESCR Committee ${ }^{95}$ and the UN Special Rapporteurs. ${ }^{96}$ Does blockage of the waiver constitute the maintenance of a barrier to faster and greater vaccine distribution? If so, that would indicate that blockage breaches extraterritorial human rights obligations to respect rights.

With regard to the pros and cons of the waiver, three issues will be investigated below. First, might a waiver of IP be a breach of the legitimate rights of pharmaceutical companies which have, quite magnificently, created miracle vaccines in record time? A related concern is that a waiver might discourage pharmaceutical companies from developing new vaccines in a future pandemic. Second, TRIPS provides for flexibilities with regard to patent rights: do they render a waiver unnecessary? Third, would a waiver of IP rights actually assist in the desired goal, the swifter manufacture of more vaccines leading to the swifter vaccination of the world?

\section{Intellectual Property as a Human Right}

Article 15(1)(c) of the ICESCR recognises the right of everyone "to benefit from the protection of the moral and material interests resulting from any scientific, literary or artistic production of which he is the author". Would a TRIPS waiver breach the rights of the pharmaceutical companies that own the relevant patents?

In General Comment 17, the CESCR Committee distinguished Article 15(1)(c) rights from IP rights by noting that the latter were "of a temporary nature" and could be "revoked, licenced or assigned to someone else", whereas human rights were "timeless expressions of the fundamental entitlements of the human person". ${ }^{97}$ The right in Article 15(1)(c) protects "the personal link between authors and their creations and between peoples, communities, or other groups and their collective cultural heritage, as well as their material interests which are necessary to enable authors to enjoy an adequate standard of living". In contrast, IP rights "primarily protect business and corporate interests and investments"..$^{98}$ In that

\footnotetext{
${ }^{94}$ Communication from the European Union to the Council for TRIPS, 'Urgent Trade Policy Responses to the COVID-19 Crisis: Intellectual Property', https://trade.ec.europa.eu/doclib/docs/2021/june/tradoc 159606.pdf, 4 June 2021.

${ }^{95}$ Statement by the Committee on Economic, Social and Cultural Rights, 'Statement on universal affordable vaccination against coronavirus disease (COVID-19), international cooperation and intellectual property', UN doc E/C.12/2021/1, 23 April 2021, paras 12-13.

96 Off. of the U.N. High Comm'r for Hum. Rts., Statement by U.N. Human Rights Experts Universal Access to Vaccine is Essential for Prevention and Containment of COVID-19 Around the World (Nov. 9, 2020), https://www.ohchr.org/EN/NewsEvents/Pages/DisplayNews.aspx?NewsID=26484\&LangID=E.

${ }^{97}$ Comm. on Econ., Soc. \& Cultural Rts., General Comment No. 17: The Right of Everyone to Benefit from the Protection of the Moral and Material Interests Resulting from Any Scientific, Literary or Artistic Production of which He or She is the Author, U.N. Doc. E/C. 12/2000/17, ๆ 2 (Jan. 12, 2006).

98 Comm. on Econ., Soc. \& Cultural Rts., General Comment No. 17: The Right of Everyone to Benefit from the Protection of the Moral and Material Interests Resulting from Any Scientific, Literary or Artistic Production of which He or She is the Author, U.N. Doc. E/C. 12/2000/17, ๆ 2 (Jan. 12, 2006).
} 
respect, the CESCR Committee underlined that Article 15(1)(c) rights vest only in human beings rather than corporations. ${ }^{99}$ Furthermore, the CESCR Committee anticipated that a variety of regimes, including but not limited to IP -like regimes, could satisfy Article $15(1)(c) .{ }^{100}$

Regarding COVID-19 and IP, the UN Special Rapporteurs said:

Intellectual property rights should not override States' obligations to protect and fulfil the right to health, which entails providing for immunization and treatment against major infectious diseases to all without discrimination. ...

Furthermore:

Industry and private benefit cannot be prioritized over the rights to life and health of billions with so far-reaching consequences. ${ }^{101}$

Given the grave impact of COVID-19 on lives, health, livelihoods, and national and global economies, it seems clear that the rights to health and life must override any claim that pharmaceutical companies would have to countervailing 'human rights' under international human rights law.

\section{IP as a facilitator of pharmaceutical production}

IP rights are said to be justified by the rewards they deliver to creators, innovators, inventors and authors, and the consequent boost they deliver to research and development. IP protection of life-saving drugs is said to be needed in order to incentivise the research and development ('R \& $D$ ') which leads to the creation of those drugs. While patent protection may reduce accessibility, it is nevertheless better that a pharmaceutical product, such as a COVID-19 vaccine, is available to some rather than non-existent and available to no one. Hence, perhaps one can argue that the rights to health and life are ultimately prejudiced by a waiver of IP rights. While it might help in the short term, it might disincentivise the creation of new vaccines, which will probably be needed on an ongoing basis to address variants, as well as medicines needed for the next pandemic. ${ }^{102}$

In response, one may note that it is the developing world that is, largely, most desirous of the waiver. In 2013, the UN Special Rapporteur on the Right to Health reported that $95 \%$ of

99 Comm. on Econ., Soc. \& Cultural Rts., General Comment No. 17: The Right of Everyone to Benefit from the Protection of the Moral and Material Interests Resulting from Any Scientific, Literary or Artistic Production of which He or She is the Author, U.N. Doc. E/C. 12/2000/17, 17 (Jan. 12, 2006).

100 Comm. on Econ., Soc. \& Cultural Rts., General Comment No. 17: The Right of Everyone to Benefit from the Protection of the Moral and Material Interests Resulting from Any Scientific, Literary or Artistic Production of which He or She is the Author, U.N. Doc. E/C. 12/2000/17, ๆ 16, 47 (Jan. 12, 2006).

${ }^{101}$ See also Statement by the Committee on Economic, Social and Cultural Rights, 'Statement on universal affordable vaccination against coronavirus disease (COVID-19), international cooperation and intellectual property', UN doc E/C.12/2021/1, 23 April 2021, para 11.

102 See R.M. Hilty, 'COVID-19 and the Role of Intellectual Property', Position Statement of the Max Planck Institute for Innovation and Competition of 7 May 2021, 5. See also Sarah Joseph, Pharmaceutical Corporations and Access to Drugs: The 'Fourth Wave' of Corporate Human Rights Scrutiny, 25 Hum. Rts. Q. 425, 431-32 (2003). 
the sales of new medicines launched from 2004-2008 took place in North America, Europe and Japan, while Africa and the rest of Asia accounted for only 5\% of sales. ${ }^{103}$ The developing world component of the patented pharmaceutical market is small, so it makes little difference to the amounts available for pharmaceutical R\&D resources. ${ }^{104}$

In any case, much of the R\&D into the creation of new drugs is undertaken at public expense in government and university laboratories. ${ }^{105}$ The initial basic research into a drug is often publicly funded, which is the high risk phase with regard to the predictability of future marketability, ${ }^{106}$ though public funds may also assist in the later stages of drug development, particularly clinical trials. The prevalence of public R\&D funding for pharmaceutical products again indicates that R\&D budgets could remain robust if patent rights were decreased.

The development of COVID-19 vaccines was facilitated by massive investments from governments and philanthropic organisations. ${ }^{107}$ The AstraZeneca vaccine was developed by Oxford University and was reportedly $97 \%$ publicly funded. ${ }^{108}$ Moderna was developed by US government money, while Pfizer benefited from assistance from Germany as well as guaranteed pre-purchase contracts which underwrote risk. ${ }^{109}$ Both the Pfizer and Moderna mRNA vaccines benefit from licensing agreements with the US's public National Institute of Health, which owns patented technology that makes mRNA vaccines possible. ${ }^{110}$ Even COVAX invested in manufacturing capacities prior to the end of vaccine clinical trials. As noted by Eccleston-Turner and Upton, such arrangements privatised the profits but socialised the risks in vaccine development. ${ }^{111}$

Serious questions may also be raised regarding actual innovation in the pharmaceutical industry. As stated by the CESCR Committee in General Comment 25 at paragraph 61:

... intellectual property can sometimes create distortions in the funding of scientific research as private financial support might go only to research projects that are profitable, while funding to address issues that are crucial for economic, social and

\footnotetext{
${ }^{103}$ Rep. of Paul Hunt (Special Rapporteur) on the Right of Everyone to the Enjoyment of the Highest Attainable Standard of Physical and Mental Health, U.N. Doc. A/63/263, annex, ๆ 13 (Aug. 11, 2008).

${ }^{104}$ Amy Kapczynski \& Jishian Ravinthiran, How to Vaccinate the World: Part 2, Law and Political Economy Project Blog (May 4, 2021), https://Ipeproject.org/blog/how-to-vaccinate-the-world-part-2.

${ }^{105}$ Rep. of Paul Hunt (Special Rapporteur) on the Right of Everyone to the Enjoyment of the Highest Attainable Standard of Physical and Mental Health, U.N. Doc. A/63/263, annex (Aug. 11, 2008).

${ }^{106}$ Ekaterina Galkina Cleary et al., Contribution of NIH Funding to New Drug Approvals 2010-2016, 115 Proc. of the Nat'I Acad. of Sci. of the U.S.A. 2329 (2018). See also Joseph Stiglitz, Making Globalization Work 111 (2007); Ha-Joon Chang, Kicking Away the Ladder: Development Strategy in Historical Perspective 31 (2005). 107 Siva Thambisetty et al., 13 (citing the figure of $€ 85.6$ into the development of vaccines).

108 Michael Safi, Oxford/AstraZeneca COVID Vaccine Research 'was 97\% Publicly Funded', The Guardian (Apr. 15, 2021, 2:00 PM), https://www.theguardian.com/science/2021/apr/15/oxfordastrazeneca-covid-vaccineresearch-was-97-publicly-funded.

${ }^{109}$ Amy Kapczynski, How to Vaccinate the World, Part 1, Law and Political Economy Project Blog (Apr. 30, 2021), https://lpeproject.org/blog/how-to-vaccinate-the-world-part-1/.

${ }^{110}$ Rebecca Robbins \& Peter S. Goodman, Pfizer Reaps Hundreds of Millions in Profits from COVID Vaccine, The New York Times (May 4, 2021), https://www.nytimes.com/2021/05/04/business/pfizer-covid-vaccineprofits.html ${ }^{111}$ Mark Eccleston-Turner \& Harry Upton, 8.
} 
cultural rights might not be adequate, as these issues do not seem financially attractive for business. This has been the case with the so-called neglected diseases.

IP incentivises R\&D into drugs which treat chronic, ongoing conditions, like heart disease or high cholesterol, as opposed to cures and, ironically, vaccines, which do not have the same ongoing market potential. ${ }^{112}$ Only four companies were reportedly making vaccines for the US at the beginning of 2020, compared to over twenty in the 1970s. ${ }^{113}$ Dr Paul Stoffels, chief scientific officer at Johnson \& Johnson, admitted in June 2020 that: "there is no real incentive to [make vaccines], no financial incentive", reflecting on the failure of the industry to create vaccines in light of previous novel coronaviruses such as SARS and MERS. ${ }^{114}$ Thambisetty et al have suggested that IP may incentivise boosters for rich countries instead of first doses for poorer countries. ${ }^{115}$

There are also arguments that IP protection restricts R\&D by preventing non-IP holders from building on the patented R\&D. Patentees may for example refuse to license competitors so as to diminish the chances of an R\&D breakthrough by a rival. ${ }^{116}$ Useful knowledge, which might likely lead to more useful knowledge, is 'locked up' ${ }^{117}$ IP also discourages the sharing of information and potentially fruitful cooperation in solving medical problems. While the new mRNA technologies are wondrous, how much better and quicker might outcomes have been had Pfizer and Moderna worked together? ${ }^{118}$ Other companies, such as GlaxoSmithKline ('GSK'), are currently working on their own vaccines, which may or may not succeed in clinical trials. However, the global good might be better served by them using their considerable manufacturing capacities to produce existing vaccines now. ${ }^{119}$ IP regimes do not incentivise GSK to divert resources from its own potential blockbuster product to the manufacture of its competitors' property.

Finally, whatever the rationale for IP, IP law has facilitated major market failure in the current COVID-19 crisis. As explained by Thambisetty et al:

\footnotetext{
112 Anna-Marie Tabor, Recent Developments: AIDS Crisis, 38 Harv. J. on Legis. 514, 524 (2001); Siva Thambisetty et al., 41-42.

113 Jay Hancock, They Pledged to Donate Rights to Their COVID Vaccine, Then Sold Them to Pharma, Kaiser Health News (Aug. 25, 2020), https://khn.org/news/rather-than-give-away-its-covid-vaccine-oxford-makes-adeal-with-drugmaker/.

${ }^{114}$ Knvul Sheikh \& Katie Thomas, Researchers Are Racing to Make a Coronavirus Vaccine. Will It Help?, The New York Times (Jan. 28, 2020), https://www.nytimes.com/2020/01/28/health/coronavirus-vaccine.html. 115 Siva Thambisetty et al., 13.

${ }^{116}$ Mark Eccleston-Turner, Beyond Patents: Scientific Knowledge, and Access to Vaccine, 3 Ethics, Medicine and Public Health 64, 69 (2017)

117 Siva Thambisetty et al., 38-40; See, e.g., Peter Drahos with John Braithwaite, Information Feudalism: Who Owns the Knowledge Economy?, 3 (2002) (on Myriad's IP rights over BRCA1 and BRCA 2 genes which may deter further research into the genes' connection to breast and ovarian cancer).

${ }^{118}$ E.g., Moderna's product had an early advantage regarding the temperature it could be stored at, which may have prevented instances of spoiled Pfizer vaccines had it been shared.

${ }^{119}$ Caleb Watney, How the U.S. Can Solve the Global Vaccine Shortfall, Agglomerations (Apr. 7, 2021), https://www.agglomerations.tech/how-the-us-can-solve-the-global-vaccine-shortfall/.
} 
... patent law is fundamental to the way the pharmaceutical market is constructed; and as such patent law must be considered a key factor when the market produces dysfunctional and inequitable results, as it is doing now during the COVID-19 crisis. ${ }^{120}$

\section{Other arguments in favour of IP protection for COVID-19 vaccines}

A 'national security' argument has been made that the US must maintain its edge in vaccine technologies, especially mRNA, over Russia and China. ${ }^{121}$ The use of national security in this context is odd: vaccine technology would be used by other countries to save lives rather than drop bombs. However desirable an "edge" in vaccine diplomacy might be under realpolitik, it is no justification for policies that block increased manufacture and delivery of vaccines. There are also huge diplomacy upsides in adopting policies that increase such manufacture and delivery, including support for the waiver.

Bill Gates, the billionaire founder of Microsoft, heads the Bill and Melinda Gates Foundation, which has funded countless public health initiatives in the last twenty years. Accordingly, he has played a prominent role in global public health policy. Gates is a strong supporter of IP rights, and has criticised the waiver proposal. One argument he raised is that IP requirements help to ensure control over vaccine production by patent owners, which ensures that the resulting products are safe. ${ }^{122}$ This argument entails a sleight of hand, however, as safety is not the raison d'etre for IP rights. ${ }^{123}$ Domestic regulatory processes manage safety concerns for medicines aside from IP. If IP was justified by safety concerns, one might wonder why IP rights ever expire. ${ }^{124}$

Overall, we conclude that the human rights arguments in favour of patent protection are outweighed by the arguments in favour of at least occasional relaxation of patents to facilitate access to life-saving drugs, such as the COVID-19 vaccines, especially in developing states.

\section{TRIPS flexibilities}

Does a waiver-less TRIPS treaty mandate breaches of human rights? ${ }^{125}$ The CESCR Committee stated in General Comment 25:

A balance must be reached between intellectual property and the open access and sharing of scientific knowledge and its applications, especially those linked to the realization of other economic, social and cultural rights, such as the rights to health,

\footnotetext{
120 Siva Thambisetty et al., 12.

${ }^{121}$ Hannah Kuchler \& Aime Williams, Vaccine Makers Say IP Waiver Could Hand Technology to China, Financial Times (Apr. 25, 2021), https://www.ft.com/content/fa1e0d22-71f2-401f-9971-fa27313570ab.

122 Sissi Cao, Bill Gates' Comments on COVID-19 Vaccine Draw Outrage, Observer (Apr. 28, 2021, 8:30 AM), https://observer.com/2021/04/bill-gates-oppose-lifting-covid-vaccine-patent-interview/. See also Oliver Pieper, Coronavirus Vaccine: Did Pfizer Put Profit First?, DW (Feb. 21, 2021), https://www.dw.com/en/coronavirus-vaccine-did-pfizer-put-profit-first/a-56622056 (for Pfizer's comment). ${ }^{123}$ Siva Thambisetty et al., 50.

${ }^{124}$ Gates seemed to change his mind very quickly to support the Biden administration's view on the waiver: https://www.devex.com/news/gates-foundation-reverses-course-on-covid-19-vaccine-patents-99810 ${ }^{125}$ See Sarah Joseph, Blame It on the WTO ch. 2.B (2011) (for further discussion on this issue. But note that the question of the resolution of any such normative conflict is beyond the scope of this article).
} 
education and food. The Committee reiterates that ultimately, intellectual property is a social product and has a social function and consequently, States parties have a duty to prevent unreasonably high costs for access to essential medicines ... from undermining the rights of large segments of the population to health .... ${ }^{126}$

TRIPS allows for exceptions which support countervailing public health rights, and may perhaps achieve the 'balance' sought by the CESCR Committee. In particular, Article 31 permits states to issue compulsory licences in respect of the generic manufacture of patented goods for a particular purpose without the consent of the patent holder.

The licence may prescribe that the government itself manufactures the product, or that a third party, such as a generic drugs manufacturer, is authorised to make and sell the product. Under paragraph (b), the issuing of a compulsory licence must be preceded by genuine negotiations with the patent-holder to seek a voluntary licence on reasonable commercial terms. This condition is waived in times of 'national emergency or other circumstances of extreme urgency' or in the case of government manufacture and use. The patent-holder must nevertheless be notified as soon as possible in such circumstances.

In 2001, developing states faced a massive HIV-AIDS crisis, and argued that they were priced out of the market for HIV drugs which were widely available, and saving lives, in developed states. Early that year, South Africa faced a lawsuit from 39 pharmaceutical companies against its Medicines and Related Substances Control Amendment Act 1997, which introduced various measures to control drug prices. ${ }^{127}$ Brazil faced a WTO complaint from the US over its use of its compulsory licensing regime and its threats to expand it in order to provide HIV-AIDS therapies at a reasonable cost to its stricken population. ${ }^{128}$ It is likely that both states were actually complying with TRIPS, but were being pressured to forego the use of legitimate flexibilities. ${ }^{129}$

Amidst these controversies, developing states campaigned inside and outside the WTO to clarify the scope of certain TRIPS flexibilities, including its compulsory licensing provisions. The pharmaceutical companies and the US were pressured to withdraw their actions against, respectively, South Africa and Brazil. Ultimately, the Declaration on the TRIPS Agreement and Public Health was adopted in December 2001 ('the Doha Declaration'). ${ }^{130}$

Importantly, the Doha Declaration clarified that TRIPS 'can and should be interpreted and implemented in a manner supportive of WTO members' right to public health and, in particular, promote access to medicines for all'. Furthermore, 'public health crises, including those relating to HIV/AIDS, tuberculosis, malaria and other epidemics' were recognized as

\footnotetext{
${ }^{126}$ Comm. on Econ., Soc. \& Cultural Rts., General Comment No. 25 (2020) on Science and Economic, Social and Cultural Rights, U.N. Doc. E/C. 12/GC/25, ๆ 62 (Apr. 30, 2020).

127 Pat Sidley, Drug companies sue South African government over generics, 322 British Med Jnl 7284 (24 Feb 2001).

${ }^{128}$ See Brazil-Measures Affecting Patent Protection, WTO Doc G/L/454/IP/D/23/Add.1/WT/DS199/4, 19 July 2001.

${ }^{129}$ Sarah Joseph, Pharmaceutical Corporations and Access to Drugs: The 'Fourth Wave' of Corporate Human Rights Scrutiny, 25 Hum. Rts. Q. 425, at 442-45 (2003)

130 WTO, Ministerial Declaration of 20 November 2001, WTO Doc. WT/MIN(01)/DEC/2.
} 
national emergencies for the purposes of issuing a TRIPS compliant compulsory licence. COVID-19 surely constitutes a comparable or even larger public health emergency.

Another breakthrough arose within the WTO in 2003. One general restriction in TRIPS on compulsory licences is that the licence, under Article 31(f), must be issued 'predominantly for the supply of the domestic market'. Yet many states lack the capacity to manufacture generic pharmaceutical products. The ability of such states to import compulsorily licensed products is limited under Article 31(f) because other states are prohibited from producing such generic goods primarily for export. In 2003, the WTO's General Council waived the territorial restriction on compulsory licences for pharmaceutical products in certain circumstances so as to permit exports of compulsorily licensed pharmaceutical products to states that lack local manufacturing capacity. ${ }^{131}$ The waiver was cemented by a formal amendment to TRIPS, Article 31bis, which entered into force in 2017.

There are extensive procedural prerequisites for use of the Article 31bis mechanism. For example, there are detailed notice requirements for both the importer and exporter to the TRIPS Council. Safeguards must be implemented, for example to ensure that the compulsory licensed generics are not diverted to another market. The formalities have been criticised as being overly cumbersome and costly. ${ }^{132}$ They may partially explain why the Article 31 bis process has been used only once in its history (prior to its formalization in the TRIPS treaty) to authorize the export of anti-HIV drugs by Canada to Rwanda. ${ }^{133}$

In his 2009 Report to the UN Human Rights Council, the Special Rapporteur on the Right to Health, Anand Grover, concluded that TRIPS obligations did not conflict with rights of access to medicines due to the available TRIPS flexibilities. ${ }^{134}$ He urged states to utilise all available TRIPS flexibilities, as needed, in order to ensure access to medicines domestically. Their common failure to do so amounted in Grover's view to a violation of the right to health. ${ }^{135}$

Furthermore, the placement of pressure on weaker states by stronger states to forego TRIPS flexibilities, ${ }^{136}$ such as to diminish the former's ability to provide access to medicines for their populations, constitutes an extraterritorial breach of the duty to respect human rights obligations by the latter states. Pharmaceutical companies also apply pressure and even reportedly lobbied the US to punish countries over compulsory licensing proposals for COVID-19 drugs, and for advocating in favour of the waiver (prior to the US signalling its own support for a waiver). ${ }^{137}$

\footnotetext{
${ }^{131}$ Decision of the General Council, Implementation of Paragraph 6 of the Doha Declaration on the TRIPS Agreement and Public Health, WTO Doc. WT/L/540 (Aug. 30, 2003).

132 Nicholas G. Vincent, Trip-ing Up: The Failure of TRIPS Article 31bis, 24 Gonzaga J. of Int'I L. 1, 22 (2020).

133 Id, at 2, 19.

${ }^{134}$ Rep. of Anand Grover (Special Rapporteur) on the Right of Everyone to the Enjoyment of the Highest Attainable Standard of Physical and Mental Health, U.N. Doc. A/HRC/11/12, ๆ 94 (Mar. 31, 2009).

${ }^{135}$ See also Adam McBeth, International Economic Actors and Human Rights 140 (2009).

${ }^{136}$ Nicholas G. Vincent, Trip-ing Up: The Failure of TRIPS Article 31bis, 24 Gonzaga J. of Int'I L. 1, 23 (2020).

${ }^{137}$ Lee Fang, Drug Lobby Asks Biden to Punish Foreign Countries Pushing for Low-Cost Vaccines, The Intercept (Mar. 4, 2021, 4:06 AM), https://theintercept.com/2021/03/03/vaccine-coronavirus-big-pharma-biden/.
} 
Compulsory licensing could be of some use in addressing COVID-19 vaccine shortages. In early May 2021, Bolivia announced that it would be seeking a supply of COVID-19 vaccines from a Canadian company, Biolyse, under Article 31bis. ${ }^{138}$ At the time of writing, Canada had not granted a compulsory license to the company.

However, compulsory licensing seems less likely to be of great use in boosting vaccine production compared to, for example, its utility in increasing access to HIV-drugs. It is relatively easy to reverse engineer chemical compounds and prove product equivalence between generic and patented medicines. It is much more difficult to prove bioequivalence between a generic and a patented biologic such as a vaccine, due to their 'complex structure and manufacturing process' ${ }^{139}$ Hence, generic products cannot simply rely on the clinical trial data of the patented vaccines: further procedures to prove safety and efficacy will likely be necessary, which is costly and time-consuming. ${ }^{140}$ Furthermore, some of the Article 31 bis safeguards designed to stop leakage of compulsory licensed products into unauthorised markets may not be possible with biologics. While the colour, shape and imprint of pills can clearly distinguish generic drugs from patented drugs, the same is not true of liquid in a vial. ${ }^{141}$

Furthermore, the complexity of vaccines means that they are often the subject of multiple overlapping patents registered by different entities. ${ }^{142}$ For example, mRNA vaccines may be the subject of dozens of patents with regard to their components and manufacturing processes. ${ }^{143}$ These 'patent thickets' ${ }^{144}$ stall compulsory licensing initiatives significantly, with a license being needed for each patent. Yet speed is essential to vaccinate the world against COVID-19.

The TRIPS regime provides weaker IP protection than "TRIPS-plus" regimes which are commonly adopted within regional or bilateral trade treaties, especially by the US. ${ }^{145}$ For example, they might provide for data exclusivity which might force a generic competitor to conduct new clinical trials. ${ }^{146}$ Some also tighten compulsory licensing requirements. The

\footnotetext{
${ }^{138}$ Biolyse Pharma press release, 'Bolivia and Biolyse sign landmark agreement for export of COVID-10 vaccines', Newswire Canada, https://www.newswire.ca/news-releases/bolivia-and-biolyse-sign-landmarkagreement-for-export-of-covid-19-vaccines-832670191.html, 12 May 2021; Siva Thambisetty et al., 36. ${ }_{139}$ Mark Eccleston-Turner, Beyond Patents: Scientific Knowledge, and Access to Vaccine, 3 Ethics, Medicine and Public Health 64, 67 (2017). See also Nicholas G. Vincent, Trip-ing Up: The Failure of TRIPS Article 31 bis, 24 Gonzaga J. of Int'I L. 1, 24-27 (2020).

140 Mark Eccleston-Turner, Beyond Patents: Scientific Knowledge, and Access to Vaccine, 3 Ethics, Medicine and Public Health 64, 67 (2017).

${ }^{141}$ Nicholas G. Vincent, Trip-ing Up: The Failure of TRIPS Article 31bis, 24 Gonzaga J. of Int'I L. 1, 25 (2020).

142 Jocelyn Bosse et al., TRIPS Waiver: There's More to the Story Than Vaccine Patents, The Conversation (May 8, 2021, 2:37 AM), https://theconversation.com/trips-waiver-theres-more-to-the-story-than-vaccine-patents160502.

143 Public Citizen, Waiver of the WTO's Intellectual Property Rules: Facts vs. Common Myths, Public Citizen: COVID Vaccines For All: WHO TRIPS Waiver Now 3 (Mar. 29, 2021), https://www.citizen.org/article/waiver-ofthe-wtos-intellectual-property-rules-myths-vs-facts/.

144 Mark Eccleston-Turner, Beyond Patents: Scientific Knowledge, and Access to Vaccine, 3 Ethics, Medicine and Public Health 64, 69-70 (2017).

${ }^{145}$ Sarah Joseph, Blame it on the WTO 241-243 (2011).

${ }^{146}$ Comm. on Econ., Soc. \& Cultural Rts., General Comment No. 25 (2020) on Science and Economic, Social and Cultural Rights, U.N. Doc. E/C. 12/GC/25, ๆ 61 (Apr. 30, 2020).
} 
TRIPS-plus provisions seem to contravene the spirit of cooperation engendered within the WTO by the Doha Declaration and Article 31bis. ${ }^{147}$

\section{Would a TRIPS waiver help?}

The strongest argument against a TRIPS waiver regarding COVID-19 vaccines is that it would not achieve its goal of increasing vaccine manufacture and access across the world. ${ }^{148}$ In an open letter to US President Biden on 5 March 2021, which urged the US government to resist the TRIPS waiver, ${ }^{149}$ a group of pharmaceutical companies claimed:

COVID-19 vaccines are complex biologic products. The manufacturing requires specialized experience, expertise and equipment. For example, only a few facilities in the world perform some of the critical steps needed to manufacture mRNA vaccines.

As noted above, compulsory licensing is largely ineffective as a cure for the scarcity of COVID-19 vaccines. Is the same true of a TRIPS waiver, generally?

\section{Why a waiver would help}

As an initial argument in favour of a waiver, one might wonder why pharmaceutical companies are lobbying so vehemently against it if it would make no difference. At present, pharmaceutical companies control access to the vaccine, as well as licenses for manufacturing the vaccine. Monopoly rights are a filter which must logically be limiting supply. Furthermore, history demonstrates that we must be wary of arguments which might underestimate global pharmaceutical manufacturing capacities, including the ability to learn and retool, especially in the Global South. Such arguments were wrong and self-serving twenty years ago in regard to anti-retroviral HIV drugs: ${ }^{150}$ they could be wrong now and deserve no benefit of the doubt. ${ }^{151}$

States must make a comprehensive effort to identify underutilised manufacturing capacity, ${ }^{152}$ and bring it online as soon as possible. Even a measure which brings forward the end of the global pandemic by as little as a month is worth it in terms of lives saved, livelihoods restored, and overall economic gains. ${ }^{153}$

\footnotetext{
147 Jean-Frédéric Morin, Tripping Up TRIPS Debates IP and Health in Bilateral Agreements, 1 J. of Intell. Prop. Mgmt. 37, 51 (2006).

${ }^{148}$ See R.M. Hilty, 'COVID-19 and the Role of Intellectual Property', Position Statement of the Max Planck Institute for Innovation and Competition of 7 May 2021.

149 The Pharm. Rsch. and Mfr. of America, https://phrma.org/Public-Communication/Letter-to-PresidentBiden-from-31-PhRMA-Board-Members (last visited June 7, 2021).

${ }^{150}$ Amy Kapczynski, How to Vaccinate the World, Part 1, Law and Political Economy Project Blog (Apr. 30, 2021), https://lpeproject.org/blog/how-to-vaccinate-the-world-part-1/; Nathan Ford et al., The First Decade of Antiretroviral Therapy in Africa, 7 Globalization and Health 33 (2011).

151 See also Siva Thambisetty et al., 50-51.

152 Hum. Rts. Watch, 'Whoever Finds the Vaccine Must Share It': Strengthening Human Rights and Transparency Around COVID-19 Vaccines, 49 (Oct. 29, 2020). See also The Independent Panel (WHO), COVID19: Make it the Last Pandemic, May 2021, 42.

153 Juan Camilo Castillo et al., Market Design to Accelerate COVID-19 Vaccine Supply, 371 Pol'y F. 1107 (2021). One option, in that regard, could be for contracts for vaccine access to 'include provisions for installing new capacity dedicated to the buyer' (Castillo et al at 108).
} 
In their open letter to President Biden, pharmaceutical companies claim that only a few facilities are able to make mRNA vaccines, and that relevant manufacturing capacity may be exhausted. ${ }^{154}$ However, it took mere half years for considerable manufacturing capacity to be scaled up from nothing for both the Pfizer and Moderna vaccines. ${ }^{155}$ There is no reason to assume that mRNA manufacturing capacity will remain static. ${ }^{156}$ For example, a recent deal between Australia and Moderna raises the possibility of Moderna being manufactured domestically in South Australia from 2022. ${ }^{157}$ In late June 2021, government authorities in another Australian state, Victoria, announced that clinical trials for locally produced mRNA vaccines were mere months away. ${ }^{158}$

In any case, the arguments regarding mRNA manufacturing capacity do not apply to nonmRNA vaccines. Significant pharmaceutical capacities exist in India, South Africa, Senegal, Egypt, ${ }^{159}$ Bangladesh, Mexico, ${ }^{160}$ Brazil, Argentina, China, South Korea, and Singapore. ${ }^{161}$ Companies in Canada, Israel, Denmark and Bangladesh have all claimed that they have offered to produce COVID-19 vaccines, but have been unable thus far to obtain a license. It also seems that India has spare existing capacity. ${ }^{162}$ A TRIPS waiver could help to maximise these factories' capacities for vaccine production.

\footnotetext{
154 Derek Rowe, Myths of Vaccine Manufacturing, Science Mag Blog (Feb. 2, 2021), https://blogs.sciencemag.org/pipeline/archives/2021/02/02/myths-of-vaccine-manufacturing. ${ }^{155}$ Amy Kapczynski, How to Vaccinate the World, Part 1, Law and Political Economy Project Blog (Apr. 30, 2021), https://lpeproject.org/blog/how-to-vaccinate-the-world-part-1/.

${ }^{156}$ Matthew M. Kavanagh et al., To Democratize Vaccine Access, Democratize Production, Foreign Policy (Mar. 1, 2021, 12:52 PM), https://foreignpolicy.com/2021/03/01/to-democratize-vaccine-access-democratizeproduction/.

157 Daniel Keane, Biotech Company Pushing to Begin Production of Australian mRNA Coronavirus Vaccine, ABC News (May 12, 2021, 12:49 PM), https://www.abc.net.au/news/2021-05-12/australian-production-of-mrnacoronavirus-vaccines/100133234.

158 Joseph Dunstan and Neelima Choahan, 'Australia's first locally made COVID-19 mRNA vaccine candidate is set for clinical trials', $A B C$ News, 20 June 2021, https://www.abc.net.au/news/2021-06-20/mrna-covid-19vaccine-trials-in-australia-variant-booster/100229294.

${ }_{159}$ Matthew M. Kavanagh et al., To Democratize Vaccine Access, Democratize Production, Foreign Policy (Mar. 1, 2021, 12:52 PM), https://foreignpolicy.com/2021/03/01/to-democratize-vaccine-access-democratizeproduction/.

160 Public Citizen, Waiver of the WTO's Intellectual Property Rules: Facts vs. Common Myths, Public Citizen: COVID Vaccines For All: WHO TRIPS Waiver Now 2 (Mar. 29, 2021), https://www.citizen.org/article/waiver-ofthe-wtos-intellectual-property-rules-myths-vs-facts/.

${ }^{161}$ Sharon Lerner \& Lee Fang, Factory Owners Around the World Stand Ready to Manufacture COVID-19 Vaccines, The Intercept (Apr. 29, 2021, 9:00 PM), https://theintercept.com/2021/04/29/covid-vaccine-factoryproduction-ip/; Hum. Rts. Watch, 'Whoever Finds the Vaccine Must Share It': Strengthening Human Rights and Transparency Around COVID-19 Vaccines, 15 (Oct. 29, 2020).

162 Ashleigh Furlong, 'Big vaccine makers reject offers to help produce more jabs', Politico, 14 May 2021; Siva Thambisetty et al., 49 .
} 
A waiver has an advantage over compulsory licensing in that it would enable a state to slice through the patent thickets described above, ${ }^{163}$ and to avoid procedural requirements regarding both manufacture and export of compulsorily licensed vaccines. ${ }^{164}$

The TRIPS waiver would represent an important normative rebuff of the standard market approach to product distribution. It would reduce the spectre of political retaliation for states that depart from IP orthodoxy in the context of COVID-19 vaccines. ${ }^{165}$ Furthermore, as noted by Thambisetty et al:

In the medium to long-term, the discussion generated by the TRIPS waiver has the potential to act as a catalyst towards structural rebalancing of monopoly market power for pandemic situations and to encourage profound changes in global pharmaceutical production and capacity. ${ }^{166}$

It would also help to rebalance power between pharmaceutical companies and governments. For example, the commercial secrecy in negotiations should be dismantled, lest it be abused to take advantage of states with weak bargaining power. There is great information asymmetry between governments, which represent people including millions infected with, and billions at risk of, COVID-19, and pharmaceutical companies representing their shareholders. ${ }^{167}$ Pricing and other conditions should be transparent, and differences justified, given the high stakes. ${ }^{168}$ At present pharmaceutical companies are able to make claims that cannot be verified due to the secrecy entailed in commercial contracts.

AstraZeneca claims that it makes no profit and that it will take a generous approach to voluntary licenses: we can only trust that AstraZeneca is abiding by its own statements. Confidentiality means that the companies cannot be held accountable for behaviour which unreasonably blocks manufacturing and further supply, ${ }^{169}$ or which gouges profits. Even

\footnotetext{
163 Public Citizen, Waiver of the WTO's Intellectual Property Rules: Facts vs. Common Myths, Public Citizen: COVID Vaccines For All: WHO TRIPS Waiver Now 3 (Mar. 29, 2021), https://www.citizen.org/article/waiver-ofthe-wtos-intellectual-property-rules-myths-vs-facts/. See also Siva Thambisetty et al., 34.

${ }^{164}$ Amy Kapczynski \& Jishian Ravinthiran, How to Vaccinate the World: Part 2, Law and Political Economy Project Blog (May 4, 2021), https://Ipeproject.org/blog/how-to-vaccinate-the-world-part-2.

165 Amy Kapczynski \& Jishian Ravinthiran, How to Vaccinate the World: Part 2, Law and Political Economy Project Blog (May 4, 2021), https:///peproject.org/blog/how-to-vaccinate-the-world-part-2. Siva Thambisetty et al., 4.

166 Siva Thambisetty et al., 5.

167 Oliver Pieper, Coronavirus Vaccine: Did Pfizer Put Profit First?, DW (Feb. 21, 2021), https://www.dw.com/en/coronavirus-vaccine-did-pfizer-put-profit-first/a-56622056 (see the statements of a former Peruvian Health Minister).

${ }^{168}$ Rep. of Paul Hunt (Special Rapporteur) on the Right of Everyone to the Enjoyment of the Highest Attainable Standard of Physical and Mental Health, U.N. Doc. A/63/263, annex (Aug. 11, 2008); Hum. Rts. Watch, 'Whoever Finds the Vaccine Must Share It': Strengthening Human Rights and Transparency Around COVID-19 Vaccines, 17 (Oct. 29, 2020).

${ }^{169}$ Hum. Rts. Watch, 'Whoever Finds the Vaccine Must Share It': Strengthening Human Rights and Transparency Around COVID-19 Vaccines, 66 (Oct. 29, 2020).
} 
COVAX negotiations are secret, so it is uncertain whether the facility is maximising vaccine affordability, which would maximise the amount of vaccines it can disperse. ${ }^{170}$

\section{More is needed}

A TRIPS waiver alone would not be a silver bullet in generating more vaccines quickly. In their October communique, India and South Africa state at paragraph 11:

Internationally, there is an urgent call for global solidarity, and the unhindered global sharing of technology and know-how in order that rapid responses for the handling of COVID-19 can be put in place on a real time basis.

As noted above regarding compulsory licensing, it is difficult to reverse engineer a vaccine. Rather, manufacturers need access to the technological know-how, including manufacturing processes, of the original manufacturer. ${ }^{171}$ Trial and error will take too long, and is unlikely to be successful anyway. ${ }^{172}$

The need for technological transfer was foreseen in May 2020, when Costa Rica headed a WHO initiative to create the COVID-19 Technological Access Pool ('C-TAP'), a depository to share innovations and expertise regarding the medicines needed to combat COVID-19 including vaccines. ${ }^{173}$ Yet the initiative has been ignored by pharmaceutical companies and developed states. ${ }^{174}$ Rather, states should be using their considerable clout to encourage and enable technology transfer and data sharing amongst companies. ${ }^{175}$ Even just the threat of the TRIPS waiver might bring pharmaceutical companies to the table in this regard to offer voluntary technology transfer. ${ }^{176}$

It is arguably a failure in extraterritorial human rights obligations for states to have failed to attach technological transfer conditions to their considerable vaccine funding. ${ }^{177}$ As noted

\footnotetext{
${ }^{170}$ Hum. Rts. Watch, 'Whoever Finds the Vaccine Must Share It': Strengthening Human Rights and Transparency Around COVID-19 Vaccines, 20 (Oct. 29, 2020); Alexandra L. Phelan et al., Legal Agreements: Barriers and Enablers to Global Equitable COVID-19 Vaccine Access, 396 The Lancet 800, at 801 (2020); Mark Eccleston-Turner \& Harry Upton, 8.

${ }^{171}$ Mark Eccleston-Turner \& Harry Upton, 9.

172 Rachel Silverman, Waiving Vaccine Patents Won't Help Inoculate Poorer Nations, The Washington Post (Mar. 16, 2021, 1:52 AM), https://www.washingtonpost.com/outlook/2021/03/15/vaccine-coronaviruspatents-waive-global-equity/.

${ }^{173}$ Hum. Rts. Watch, 'Whoever Finds the Vaccine Must Share It': Strengthening Human Rights and Transparency Around COVID-19 Vaccines, 14 (Oct. 29, 2020).

174 Public Citizen, Waiver of the WTO's Intellectual Property Rules: Facts vs. Common Myths, Public Citizen: COVID Vaccines For All: WHO TRIPS Waiver Now 4 (Mar. 29, 2021), https://www.citizen.org/article/waiver-ofthe-wtos-intellectual-property-rules-myths-vs-facts/; Emily Baumgaertner, Vaccine Companies and the U.S. Snubbed WHO Initiative to Scale Up Global Manufacturing, Los Angeles Times (Apr. 30, 2021, 5:33 PM), https://www.latimes.com/world-nation/story/2021-04-30/vaccine-companies-and-the-u-s-governmentsnubbed-who-initiative-to-scale-up-global-manufacturing. Siva Thambisetty et al., 16.

${ }^{175}$ Hum. Rts. Watch, 'Whoever Finds the Vaccine Must Share It': Strengthening Human Rights and Transparency Around COVID-19 Vaccines, 17 (Oct. 29, 2020).

176 Siva Thambisetty et al., 33.

177 Hum. Rts. Watch, 'Whoever Finds the Vaccine Must Share It': Strengthening Human Rights and Transparency Around COVID-19 Vaccines, 46 (Oct. 29, 2020). See also The Independent Panel (WHO), COVID19: Make it the Last Pandemic, May 2021, 55; R.M. Hilty, 'COVID-19 and the Role of Intellectual Property', Position Statement of the Max Planck Institute for Innovation and Competition of 7 May 2021, 6.
} 
above, the existence of such an extraterritorial duty is contentious. However, an attenuated extraterritorial duty to protect will crystallise, according to the Maastricht Principles, 'where there is a reasonable link between the state concerned and the conduct it seeks to regulate'. ${ }^{178}$ There is a 'reasonable link' between governments and the vaccines that have been created in large part with public money. While that investment must be applauded, sponsoring states must also be condemned for their failure to prevent monopoly control over vaccine outcomes. Furthermore, as noted above, this failure might be characterised as a failure in a state's intra-territorial duties to its own people, who benefit enormously from an earlier cessation of the global pandemic.

Two more suggestions, both aimed at the US, deserve attention. In March 2021, President Biden announced a deal for pharmaceutical giant Merck to manufacture the Johnson \& Johnson vaccine to more rapidly provide an extra 100 million vaccine doses for the US market. ${ }^{179}$ Such cooperation is highly unusual for two major commercial rivals. The deal may have been prompted by the possibility that the US would force cooperation under its Defense Production Act, which mandates extensive coercive governmental powers over industry for national security purposes. ${ }^{180}$ While vaccine production for the US market in a pandemic that has killed over half a million Americans is clearly a national security issue for the US, the same applies to the market beyond US shores given the pandemic's global health and economic impact, and the likely importation of new viral variants from an unvaccinated world. Hence, Kapzynski and Ravinthiram have recommended that that Act be used to prompt global technology transfers of vaccine knowledge by companies such as Pfizer and Moderna. ${ }^{181}$ Other states have similar legislative powers to forcibly mobilise industries in times of crisis and national emergency, which could be used to force more technological transfer of products that have the potential to save millions of lives. ${ }^{182}$

A second suggestion came from Caleb Watney of the Progressive Policy Institute in a compelling blog in April 2021. Watney argues that the US government should engage in a full patent and technology buyout of some of the vaccines, ${ }^{183}$ and then make them publicly available. The US government could then voluntarily license as many facilities as possible to manufacture vaccines without seeking a licensing royalty: that might be enough to convince a company like GSK to switch to the immediate production of an existing vaccine. Watney's solution has several advantages. It would be faster than the negotiation of a TRIPS waiver, which the US has already signalled will "take time". Second, while we are sceptical of the

\footnotetext{
178 Maastricht Principles, paras 24 and 25(d).

${ }^{179}$ Sheryl Gay Stolberg, Biden Announces His Intention to Secure Another 100 Million Doses of Johnson \& Johnson's Vaccine, The New York Times (Mar. 10, 2021), https://www.nytimes.com/2021/03/10/world/bidenannounces-his-intention-to-secure-another-100-million-doses-of-johnson-johnsons-vaccine.html.

180 See Defense Production Act 1950 (US). Amy Kapczynski \& Jishian Ravinthiran, How to Vaccinate the World:

Part 2, Law and Political Economy Project Blog (May 4, 2021), https://lpeproject.org/blog/how-to-vaccinatethe-world-part-2.

${ }^{181}$ Amy Kapczynski \& Jishian Ravinthiran, How to Vaccinate the World: Part 2, Law and Political Economy Project Blog (May 4, 2021), https://lpeproject.org/blog/how-to-vaccinate-the-world-part-2.

182 See, eg, Defence Production Act 1985 (Canada)

${ }^{183}$ Caleb Watney, How the U.S. Can Solve the Global Vaccine Shortfall, Agglomerations (Apr. 7, 2021), https://www.agglomerations.tech/how-the-us-can-solve-the-global-vaccine-shortfall/. See also Michael Kremer, Patent Buyouts: A Mechanism for Encouraging Innovation, 113 Q. J. of Econ. 1137 (1998).
} 
true damage to innovation that might occur with a waiver, the danger does not arise under this solution. The disadvantage is that it would cost the US a lot of money. But the amount involved, in the billions, pales in comparison to the economic pandemic losses in the trillions within the US, and even more so globally, alongside humanitarian, social and cultural losses. The initiative would also deliver huge diplomatic dividends to the US. Notably, however, there is no reason why Watney's suggestion could not be adapted to involve buyouts by other states of vaccine patents technologies. Our concern is not with the economic and diplomatic power of the US; it is with the development and execution of initiatives to create and deliver as many COVID-19 vaccines as is possible as quickly as is possible.

States have extraterritorial obligations, encompassed within duties to respect, protect and fulfil, to do what they reasonably can do to increase the number of COVID-19 vaccines in the world as quickly as possible. Indeed, these obligations are owed to their own people too. In that regard, the TRIPS waiver should be negotiated quickly and in good faith to remove IP obstacles to global vaccine equity. States must also pull domestic and international policy levers to facilitate technological transfer of vaccine recipes, and to utilise and scale up manufacturing capacity for vaccines. The goal, according to Watney, but which applies beyond his specific plan for global vaccination, must be to not only vaccinate the world, but to teach the world how to make vaccines in preparation for the next pandemic. ${ }^{184}$

\section{Failure of neoliberal regimes}

Article 28 of the Universal Declaration on Human Rights ('UDHR') states:

Everyone is entitled to a social and international order in which the rights and freedoms set forth in this Declaration can be fully realized.

The UDHR has arguably crystallised into customary international law, in which case Article 28 binds all states. ${ }^{185}$

The neo-liberal model for access to medicines is protected by international economic law, including TRIPS, TRIPS-plus provision and bilateral investment treaties. ${ }^{186}$ Yet that model has failed ordinary citizens in the past (for example, with regard to HIV medicines in the early 2000s), ${ }^{187}$ and is failing the world now with regard to the manufacture and distribution of COVID-19 vaccines. As stated by the UN Special Rapporteurs:

\footnotetext{
${ }^{184}$ Caleb Watney, How the U.S. Can Solve the Global Vaccine Shortfall, Agglomerations (Apr. 7, 2021), https://www.agglomerations.tech/how-the-us-can-solve-the-global-vaccine-shortfall/.

${ }^{185}$ See, e.g., Mary Ann Glendon, The Rule of Law in the Universal Declaration of Human Rights, 2 Nw. J. of Int'I Hum. Rts. 1 (2014) (note that the UDHR is not binding of itself, but there are strong arguments that it represents custom binding on all States).

${ }^{186}$ See generally, Sarah Joseph, Trade Law and Investment Law, in The Oxford Handbook of International Human Rights Law 841, 841-70 (Dinah Shelton ed., 2013).

${ }^{187}$ Fernando Pascual, Intellectual Property Rights, Market Competition and Access to Affordable Antiretrovirals, 19 Antiviral Therapy 57 (Supp. 2014).
} 
... Access and availability of a vaccine cannot be left in the hands of traditional market forces, to be defined by rules of supply and demand. Market solutions alone will not efficiently contain this pandemic nor prioritize the protection of millions of people in situations of vulnerability. ... ${ }^{188}$

Despite their avid imposition of neo-liberal orthodoxies on other states, richer states will readily depart from those orthodoxies when it is in their own interests. While UK Prime Minister Boris Johnson boisterously attributed the UK's successful vaccination program to "capitalism" and "greed", the AstraZeneca vaccine created in the UK was reportedly 97\% publicly funded. ${ }^{189}$ We did not in fact rely on the free market to provide the R\&D for vaccine development. It does not make sense to rely on it to provide for equitable vaccine distribution. ${ }^{190}$

The EU has already threatened AstraZeneca's patent due to its frustration with the company's lagging delivery plan. ${ }^{191}$ As noted, Italy and US have blocked exports in order to preserve resources for their own markets. ${ }^{192}$ This behaviour is reminiscent of the blatant hypocrisy manifested during the 'battle' over access to medicines between developed and developing states in 2001. In October 2001, the US and Canada threatened to undermine a Cipro patent for anti-anthrax drugs in light of sporadic anthrax attacks that killed five in the US, even though they had threatened developing states for daring to suggest that they might use compulsorily licensed drugs to address their critical AIDS crises. ${ }^{193}$

Yale Professor Amy Kapczynski has labelled the current situation of vaccine inequity a manmade problem of 'private power and monopoly'. ${ }^{194}$ The IP and secrecy rights of pharmaceutical companies limit supplies rather than share knowledge which would enable more global vaccine production. Yet this system of 'privatised control' sits atop 'a vast regime of open science and public subsidy', including the free sharing of the COVID-19 viral sequence from China in early 2020 and massive government funding towards vaccine development including pre-pandemic discoveries. This system is then protected under international economic law. As stated by Kapczysnski:

\footnotetext{
188 Off. of the U.N. High Comm'r for Hum. Rts., Statement by U.N. Human Rights Experts Universal Access to Vaccine is Essential for Prevention and Containment of COVID-19 Around the World (Nov. 9, 2020), https://www.ohchr.org/EN/NewsEvents/Pages/DisplayNews.aspx?NewsID=26484\&LangID=E. See also UNESCO, Venice Statement on the Right to Enjoy the Benefits of Scientific Progress and its Applications, U.N. Doc. SHS/RSP/HRS-GED/2009/PI/H/1 (2009), ๆ 3(ii).

${ }_{189}$ Michael Safi, Oxford/AstraZeneca COVID Vaccine Research 'was 97\% Publicly Funded', The Guardian (Apr. 15, 2021, 2:00 PM), https://www.theguardian.com/science/2021/apr/15/oxfordastrazeneca-covid-vaccineresearch-was-97-publicly-funded.

190 Siva Thambisetty et al., 47.

${ }^{191}$ Ashleigh Furlong \& Sarah Anne Aarup, Europe Hints at Patent Grab From Big Pharma, Politico (Feb. 3, 2021, 8:50 PM), https://www.politico.eu/article/europe-patent-grab-big-pharma/

192 X-ref.

${ }^{193}$ Sarah Joseph, Pharmaceutical Corporations and Access to Drugs: The 'Fourth Wave' of Corporate Human Rights Scrutiny, 25 Hum. Rts. Q. 425, at 446-47 (2003)

${ }^{194}$ Amy Kapczynski, How to Vaccinate the World, Part 1, Law and Political Economy Project Blog (Apr. 30, 2021), https://lpeproject.org/blog/how-to-vaccinate-the-world-part-1/.
} 
The rules of global markets are not just unequal but extractive. They reproduce colonial dynamics in new forms. ${ }^{195}$

Indeed, while we have emphasised the vaccine divide in this article in the polite language of 'developed' and 'developing' states, that divide is the same as between coloniser and colonised states, reflecting a stark racial divide too.

The global IP rights ordained by TRIPS are not yet 30 years old, and have always been controversial. The treaty is an odd fit within the WTO, given it mandates trade restrictions amongst a suite of treaties devoted to freer trade. ${ }^{196}$ Notably, the most ferocious lobbyists for TRIPS, in a campaign that built throughout the 1980s, were the US and a cabal of pharmaceutical companies including Pfizer. ${ }^{197}$

TRIPS mandates a regressive transfer of wealth from poor countries to rich countries, as most IP continues to be held in the latter. ${ }^{198}$ TRIPS constrains the developmental capacities of developing states in ways not experienced by today's developed states, which benefited from their own industrialising periods as bold IP pirates. ${ }^{199}$ The result, as noted in the following passage from Anne Orford, was foreseeable:

The current scarcity of vaccines is the predictable effect of a system that allows the use of monopoly rights to control pharmaceutical production globally. The result is a moral catastrophe as well as an ongoing public health and economic crisis. The ability of a handful of powerful companies based in Europe and the US to claim property rights over innovations resulting from the collective processes of modern science, and to use those rights to control the pace of manufacture and the price of pharmaceutical products, is not an unfortunate side effect of this system but its goal. ${ }^{200}$

Part of the TRIPS bargain for the global South at the time of its adoption in 1994 was the promise of greater technology transfer. ${ }^{201}$ Instead, TRIPS has reinforced the technical

\footnotetext{
195 Amy Kapczynski, How to Vaccinate the World, Part 1, Law and Political Economy Project Blog (Apr. 30, 2021), https://Ipeproject.org/blog/how-to-vaccinate-the-world-part-1/.

${ }^{196}$ See, e.g., Jagdish Bhagwati, Afterword: The Question of Linkage, 96 Am. J. of Int'I L. 126, 128 (2002).

197 Anne Orford, Broken Bargains, London Review of Books: Blog (May 5, 2021),

https://www.Irb.co.uk/blog/2021/may/broken-bargains. Note that many developed States eschewed patents in the pharmaceutical industry well into the twentieth century, such as France (they became patentable in 1960), Ireland (1964), Germany (1968), Japan (1976), Switzerland (1977), Italy (1978), Sweden (1978) and Spain (1992): see G. Dutfield and U. Suthersanen, Dutfield and Suthersanen on Global Intellectual Property 172 (2020).

198 Sarah Joseph, Blame It on the WTO 153 (2011).

${ }^{199}$ Ha-Joon Chang, Kicking Away the Ladder: Development Strategy in Historical Perspective 57, 84-85 (2005); Robert Wade, What Strategies are Viable for Developing Countries Today? The World Trade Organization and the Shrinking of Policy Space, 10 Rev. of Int'I Pol. Econ. 621, 626 (2003).

${ }^{200}$ Anne Orford, Broken Bargains, London Review of Books: Blog (May 5, 2021),

https://www.Irb.co.uk/blog/2021/may/broken-bargains.

201 Siva Thambisetty et al., 2.
} 
dominance of the global North, ${ }^{202}$ which is reflected in its creation of what seem, to date, to be the best COVID-19 vaccines. As noted above, Anand Grover concluded that TRIPS did not mandate breaches of the right to health in his report as Special Rapporteur in 2009. In 2021, we see bottlenecks in vaccine manufacture exacerbated by monopoly rights and racist assumptions about the safety implications of sharing vaccine recipes with developing states. TRIPS rights are enhanced by bilateral and regional TRIPS plus measures, as well as rights under bilateral investment treaties which further shrink the policy space of states. ${ }^{203}$ The soft law human rights responsibilities on companies outlined by the UNGPs, explained above, provide no real counterweight. In these circumstances, at this time, Article 28 of the UDHR is not being respected: we do not have a social and international order in which the many rights compromised by the pandemic can be enjoyed on an equitable basis across the world.

\section{Part 4: Conclusion}

COVID-19 vaccines have brought a miraculous light to the end of the pandemic tunnel. But that light is too far off for the vast majority of the world, simply because they live in the wrong country.

The rush to the front of the vaccine queue by rich states is probably ethically wrong, but is difficult to characterise as a breach of human rights, given that vaccines fulfil the genuine human rights of their own populations, at least prior to the vaccination of the significant part of a state's population. However, blatant oversupply changes this assessment from non-breach to breach. Export blockages of vaccines or key vaccine components is a breach of extraterritorial obligations, unless it is motivated by an urgent need to provide for home supply. Vaccine aid is a duty rather than mere charity, and must be given without unrelated conditions, either bilaterally or, preferably, via COVAX.

The biggest problem with vaccine inequity in 2021 is the simple lack of vaccines. Hence, all States have human rights obligations, both to the people of other states and to their own people, to do what they reasonably can to increase global supply, including related obligations not to obstruct initiatives that can increase global supply. In that respect, states must swiftly negotiate a waiver of TRIPS over COVID-19 vaccines. But more must be done, including all states mobilising to prompt technology transfers, for example via C-TAP, and to maximise latent manufacturing capacities towards the creation of vaccines. Pharmaceutical monopoly rights simply cannot be permitted to block progress in this regard. As Dr Tedros stated in a plaintive tweet, commenting on the need for agreement to be reached on the IP waiver, 'if not now, when'?204

\footnotetext{
202 Siva Thambisetty et al., 42. Middle income countries like China and India are increasingly competing in regard to IP rights (see Peter K. Yu, 'Intellectual Property. Global Inequality and Subnational Policy Variations', (2021 forthcoming), https://papers.ssrn.com/sol3/papers.cfm?abstract id=3760413), the Global Innovation Index is still dominated by developed States: Cornell University, INSEAS and WIPO, Global Innovation Index 2020, xxxii-xxxvi, via https://www.wipo.int/global innovation index/en/2020/

${ }^{203}$ Sarah Joseph, Trade Law and Investment Law, in The Oxford Handbook of International Human Rights Law 841, 841-70 (Dinah Shelton ed., 2013).

${ }^{204}$ Tedros Adhanom Gherbreyesus (@DrTedros), Twitter (Feb. 27, 2021, 5:40 AM), https://twitter.com/DrTedros/status/1365386263969284096?s=20.
} 